\title{
Móveis em miniatura: a demonstração de um saber fazer ${ }^{1}$
}

\section{Angela Brandão ${ }^{2}$}

RESUMO: Este artigo trata das miniaturas de móveis, as quais possivelmente despertam interesse desde que os móveis em tamanho real se tornaram elementos de civilização. Embora as miniaturas de mobília possam ser observadas por suas funções ritualísticas e mortuárias desde a Antiguidade como forma de atender às necessidades da vida além da morte, também são reconhecidas como símbolos de móveis reais e percebidas por seu caráter lúdico, como peças de brinquedo, ou por sua função, como peças de uso. Porém, há outro aspecto relativo ao elaborado processo de feitio de móveis no século XVIII, em que um artesão qualificado deveria demonstrar sua capacidade de produzir peças em miniatura perfeitamente iguais àquelas em tamanho natural. Seria possível estabelecer ainda uma via de compreensão dos móveis em miniatura: a presença de tais objetos de dimensões reduzidas na estatuária sacra brasileira colonial, tomando como exemplo o trono de Santana Mestra, o que nos leva à interpretação de um significado duplo - uma devoção específica somada à demonstração de um savoirfaire.

PALAVRAS-CHAVE: História do mobiliário. Miniaturas. Santana Mestra.

ABSTRACT: This paper is dedicated to furniture miniatures, which interest exists possibly since the natural size furniture becomes an element of civilization. Even if furniture miniatures can be seen by their ritualistic and mortuary functions since ancient times as a way to meet the needs of life beyond death, we can also observe them as real furniture symbols, perceived by their playful character, as toys; or by their function, as useful objects. But there is another aspect that refers to the elaborate process of furniture construction in the eighteenth century, in which an artisan should demonstrate its ability to produce miniature perfectly equal to those in natural size. It is possible to propose, however, another way of understanding the miniature furniture: the presence of such objects of reduced dimensions in the colonial Brazilian art, taking as an example the throne of Santana Master, which leads to the interpretation of a double meaning - an specific devotion coupled with the demonstration of a "savoir-faire".
1. Esta pesquisa contou com apoio do CNPq, Processo $\mathrm{n}^{\circ}$ 471680/2013-3 (UNIVERSAL - MCTI/CNPq n ${ }^{\circ} 14 / 2013$ ).

2. Docente do Departamento de História da Arte e do Programa de Pós-Graduação em História da Arte da Universidade Federal de São Paulo. E-mail: <bran daoangela@hotmail.com>.

KEYWORDS: Furniture history. Miniatures. Santana Master. 
3. "Como exemplo há o caso descrito pela arquiteta Cristina Sá entre os índios Karajás da aldeia Santa Isabel do Morro, na ilha do Bananal em Tocantins. Para mostrar como é a casa tradicional da estação chuvosa, o chefe Arutana escolhe uns gravetos e, de joelhos, constrói no chão uma estrutura em miniatura que representa esta arquitetura. A partir deste caso podemos afirmar extensivamente que sempre existiram maquetes, desde as sociedades neolíticas?" (Sá, 1980), Rozenstraten (2011).

4. "A crença egípcia de que a vida após a morte seguiria o mesmo padrão desta vida, seriam os 'substitutos' das coisas desse mundo no outro mundo. Acreditava-se que, através do uso de uma 'mágica' adequada, a ordem natural poderia ser subvertida: o modelo reduzido de uma 'Casa' poderia ser transformado em uma 'Casa' real, assim como figuras de pessoas poderiam ser transformadas em pessoas de carne e osso" (Rozenstraten, 2011).

5. Andrianou (2007, p. 41-50).

6. O sarcófago romano-germânico de Simpelveld (século III d.C.) do Museu Nacional de Antiguidades de Leiden mostra, em alto-relevo, em sua parte interna, as diminutas peças de mobiliário que haveriam de ter, ao menos simbolicamente, composto a casa que se habitara em vida e que continuariam, também de modo simbólico, acompanhando o morto para sempre. Ver Lucie-Smith (2000, p. 32).

7. Benjamin (1985, p. $235-$ 253).

8. O autor escreve os dois artigos em 1928, "História cultural do brinquedo" e "Brinquedo e brincadeira: observação sobre uma obra monumental", a partir da leitura da obra Gröber, Karl. Kinderspielzeug aus fascínio pelas miniaturas esteve presente em diferentes épocas e culturas. Rozenstraten afirmou ser possível reconhecer a presença disseminada de modelos tridimensionais arquitetônicos, em dimensões reduzidas, entre diferentes períodos das civilizações como uma experiência que fazia parte do processo da criação. ${ }^{3}$ A representação do mobiliário em escala reduzida já fazia parte do interesse dos egípcios antigos, capazes de desenvolver, de modo sistemático, o feitio e o uso do mobiliário em tamanho real, com um alto grau de refinamento técnico e importantes significados honoríficos. ${ }^{4} \bigcirc$ sentido funerário das representações de mobiliário em miniatura, como forma de garantir que o defunto contasse com seus pertences na vida após a morte, pode ser observado em diferentes séries e períodos de sarcófagos gregos ${ }^{5}$ e romanos. ${ }^{6}$

Diante das várias representações tridimensionais, em ambiente funerário, como nos sarcófagos antigos, nos quais uma imagem escultórica mostra o defunto comodamente recostado sobre klinés ou em prazerosas refeições apoiadas sobre mesas, sempre em dimensões reduzidas, podemos supor o sentido simbólico que estaria por trás das miniaturas de móveis, como "equivalentes para a alma" daquilo que representaram em vida, miniaturas dotadas de uma "mágica" de transposição e de transformação em direção ao objeto real.

Talvez em parte por esse sentido mágico, as miniaturas de móveis passariam a habitar constantemente o universo infantil, como peças de brinquedo. Walter Benjamin havia tratado do tema em "História cultural do brinquedo" e "Brinquedo e brincadeira", ambos de 1928.7 Para o autor, os brinquedos não foram inventados, de início, por fabricantes especializados, mas surgiram nas oficinas de entalhadores de madeira, de fundidores de estanho etc. "Somente no século XIX a produção de brinquedos será objeto de uma indústria específica", escreveu. Assim, os brinquedos derivavam, como um subproduto, "das atividades produtivas regulamentadas corporativamente, o que significava que cada oficina só podia produzir o que correspondesse ao seu ramo". ${ }^{8}$

A observação de Benjamin aproxima o mundo dos brinquedos e dos móveis em miniatura ao contexto das oficinas de artesãos organizados em corporações, cujo modelo fora herdado da ldade Média e seria mantido até a segunda metade do século XVIII, às vésperas da Revolução Industrial. Para Benjamin, portanto, cada grupo de artesãos produzia brinquedos, até o século XVIII, relacionados a seu ofício: os fundidores faziam soldados de chumbo; confeiteiros, figurinhas de doces; carpinteiros ou marceneiros, brinquedos de madeira; e assim por diante. ${ }^{9}$

A partir do século XIX, porém, "indústrias artesanais" e manufaturas passaram a dedicar-se exclusivamente a produzir diferentes tipos de brinquedos, sem a especificidade da produção puramente artesanal, até então dividida por ofícios. "Foi assim que se deu a excepcional difusão daquele mundo de coisas microscópicas, que alegrava as crianças nos armários de brinquedos [...]". 10 Para Benjamin, por essa intrínseca relação entre os brinquedos e a passagem da produção artesanal para o mundo de manufaturas e indústrias que se desenhava, 
fazia com que a história dos brinquedos, em seu conjunto, tivesse um significado muito maior. Os brinquedos não teriam uma vida autônoma e segregada, mas estabeleciam um "diálogo mudo, baseado em signos, entre a criança e o povo". 11 Justamente a passagem do brinquedo artesanal para aquele manufaturado e industrial representava a perda de seu aspecto discreto, minúsculo e sonhador para tornar-se quinquilharia. ${ }^{12}$

No microcosmo dos brinquedos artesanais, no entanto, a madeira consistia, para Benjamin, num dos materiais mais apropriados, por sua resistência e capacidade de absorver cores. As crianças eram, de resto, sóbrias, segundo o autor, com relação aos materiais. Uma vez que não estavam situadas num mundo de fantasia, tinham em seus brinquedos ou uma imitação dos utensílios e objetos dos adultos ou, ao menos, uma confrontação com eles. De acordo com Benjamin, as necessidades infantis não criam brinquedos como objetos apartados do mundo real, nem em sua aparência, nem por seu modo de produção. Os brinquedos de madeira produzidos por oficinas artesanais carregavam, em si, a demonstração transparente de seu processo de produção. Portanto, os entalhes, os aspectos formais elaborados, a imitação de técnicas refinadas, aplicadas sobre brinquedos de madeira, faziam desses pequenos objetos verdadeiras demonstrações de saberes artesanais. ${ }^{13}$

$\bigcirc$ mundo das miniaturas está relacionado com diferentes ordens culturais: a crença na continuidade da vida terrena após a morte; o significado mágico da transformação de uma réplica miniaturizada em seu equivalente de tamanho real na vida do além; o contexto dos brinquedos, entendidos em sua complexidade enquanto símbolos que permitem o diálogo com o mundo adulto, também no que se refere ao modo como os brinquedos são produzidos. Em outras palavras, nesse último sentido, a história do mobiliário em miniatura teria uma estreita relação com a história de como os móveis foram produzidos em "tamanho real". Assim, a passagem da produção artesanal dos brinquedos, no século XVIII, para a industrial, no XIX, reflete o mesmo processo de diluição que ocorria no ambiente das oficinas de produção de mobiliário, as quais haviam atingido, no Setecentos, seu mais alto grau de refinamento artesanal, técnico e estético para, em seguida, ver tal especialidade ir gradativamente ganhando contornos de manufaturas e de produção protoindustrial. ${ }^{14}$

Os móveis em miniatura não diziam respeito, no entanto, apenas ao contexto funerário e ao universo dos brinquedos. As miniaturas eram também móveis que, se considerados em proporções reais, eram destinados a determinados usos e, ao terem suas formas reduzidas, eram adaptados para funções semelhantes: cômodas em miniatura eram pequenos cofres ou porta-joias; arcas e baús corresponderiam a caixinhas para guardar objetos diminutos, e assim por diante.

De acordo com José Antônio Proença, as papeleiras em miniatura, por exemplo, estavam relacionadas ao contexto das "encomendas para senhoras". Em suas palavras, "no século XVIII, as senhoras estrangeiras [por] acompanharem os maridos nas suas viagens e, para tal, terem sentido a necessidade de se fazer alter Zeit. Eine Geshichte des Spielseugs. Berlim: Deutscher Kunstverlag, 1928. VII apud Benjamin (1985, p. 244).

9. Benjamin (1985, p. 245).

10. Benjamin (1985, p. 245)

11. Benjamin (1985, p. 248).

12. Benjamin (1985, p. 246 248). "O brinquedo começa a emancipar-se: quanto mais avança a industrialização, mais ele se esquiva ao controle da família, tornando-se cada vez mais estranho não só às crianças, como também aos pais" (Benjamin, 1985, p. 246).

13. Benjamin (1985, p. 249 253).

14. Flexor (2008). 
15. Proença (1999, p. 114, 225) apud Ana Godinho Coelho Dotti de Carvalho (2010, p. 18, 21-22).

16. Ana Godinho Coelho Dotti de Carvalho (2010, p. 21).

17. Bastos; Souza (2004, p. 22).

18. Bastos; Souza (2004, p. 22).

19. Oh et al. (2006, p. 1). acompanhar de móveis e objectos pessoais de fácil transporte". Para Proença, havia um desejo por peças em pequenas dimensões no século XVIII, em vários países - Inglaterra, França e Portugal -, realizadas de acordo com o mesmo formato dos móveis em escala real, destinadas a clientes femininas e, muitas vezes, encomendadas em pares..$^{15}$

Em seu estudo sobre uma papeleira chinesa em miniatura, Ana Godinho Carvalho demonstrou que o mobiliário em miniatura cabe, em alguns casos, ser incluído na categoria dos móveis de utilidade, por suas características formais; mesmo reduzidos, podem ser considerados como móveis de conter, de escrita, de leitura ou de desenho. ${ }^{16}$

De acordo com as normas para inventário relativas ao mobiliário, publicadas pelo Instituto Português de Museus, considera-se móvel em miniatura "um móvel de pequenas dimensões, caracterizado por apresentar em geral materiais de qualidade e execução cuidada, tendo em vista diversas finalidades. Embora a destrinça possa ser difícil, não deve ser confundido com um brinquedo". ${ }^{17}$

Ainda segundo as mesmas normas, o móvel de criança, por sua vez, deve ser entendido como "um tipo de mobiliário adequado às necessidades infantis, de dimensões menores do que as habituais e frequentemente com decoração própria". Afirma-se, aqui, mais uma vez que o móvel para crianças "não deve ser confundido com um brinquedo". Diferem-se também os modelos e protótipos que podem ser feitos em dimensões menores que as usuais. Por outro lado, as mesmas normas para inventário consideram como "prova de exame" - "um móvel de dimensões mais reduzidas, executado com materiais específicos e segundo técnicas perfeitamente idênticas às que se deveriam empregar no móvel final", recordando que "um oficial só podia obter o grau de mestre (Mestre de tenda) se tivesse prestado prova com regras e dimensões determinadas perante os juízes examinadores do seu ofício". 18

De fato, assim como para as crianças, mesmo que nos afastemos dos brinquedos, também para os artesãos e criadores adultos, o contato direto com modelos em miniatura, justamente por sua tridimensionalidade, não poderia ser substituído por nenhuma outra forma de compreensão de um objeto, nem mesmo um desenho ou uma gravura. Ainda hoje, com tantas tecnologias voltadas para as ilusões tridimensionais aplicadas à criação de produtos por programação de computadores, os designers continuam a fazer uso de protótipos tridimensionais em miniatura. ${ }^{19}$

No entanto, se nos ativermos ao contexto que antecede a transformação da produção artesanal de móveis, veremos a presença das miniaturas relacionadas ao alto grau de especialização dos saberes e fazeres dos marceneiros no decorrer do século XVIII. Apesar de reconhecermos o fenômeno das miniaturas no contexto artesanal português do Setecentos, cujas características se estenderam sobre a produção artística brasileira, o desenho tinha reconhecida importância como a forma mais adequada para elaboração de peças. Não obstante, costumou-se afirmar, equivocadamente, que havia um forte aspecto de empirismo entre os 
artífices que atuaram no contexto luso-brasileiro até o século XVIII, em detrimento de um conhecimento teórico e erudito. Porém, tal afirmação vem sendo gradativamente matizada, por exemplo, ao estudar-se a circulação de tratados artísticos no ambiente dos oficiais mecânicos. ${ }^{20}$

Para Jaime Souza, com efeito, desde o século XVII o móvel em Portugal passa a ser "objeto de um olhar mais consciente e atento, momento decisivo do seu processo de autonomização que culminará no século XVIII", propondo a hipótese de circulação, entre marceneiros, de tratados como o de Hans Vredeman de Vries. ${ }^{21}$ Para se compreender a circulação do conhecimento dos tratados de arquitetura e a importância do desenho como um modelo consciente, no ambiente dos artesãos, Julius Schlosser havia indicado a existência dessa transmissão de saberes eruditos, contidos em tratados como os de Serlio e Vignola, por meio de livros simplificados. Tais publicações "populares" eram escritas e lidas sobretudo entre carpinteiros, ebanistas e entalhadores, capazes de reduzir os elementos arquitetônicos às dimensões dos retábulos, móveis ou caixas. Em oposição à literatura aristocrática, marcada pelo ambiente de corte, Schlosser evocava versões limitadas ao ambiente artesão e pequeno-burguês, como libretos populares sobre as cinco ordens, os chamados, mais tarde, Säulenbuchlein. Alguns desses tratatelli ainda guardavam semelhanças com os scapellini góticos, mas já dependiam de Vitrúvio e especialmente de Serlio. ${ }^{22}$

Em 1565, o chamado "Vitruvio Flamengo", Vredeman de Vries - a quem se referia Jaime Souza - publicou, nos Países Baixos, o livro L'Architectura. Sua absorção por ebanistas levou à construção de móveis como templos domésticos - com aspecto monumental, baseados nos princípios de Vitrúvio, Serlio e Vignola e elaborados com elementos arquitetônicos como as colunas das ordens clássicas. ${ }^{23}$

Num dos primeiros tratados artísticos redigidos em língua portuguesa, de Félix da Costa, Antiguidade da arte da pintura, 1685-1688, reconhecia-se a importância do desenho também para a formação e a atividade dos artesãos da madeira. Em suas palavras:

\footnotetext{
Couza $\mathrm{m}^{\text {to }}$. Necessaria aos Pintores, Escultores e Arquitectos; porque todas estas tres Artes requerem $m^{\text {to }}$ Debuxo... M..$^{\text {to }}$ conveninte aos Engenheiros... Aos ourives do Ouro e da Prata muy necessario, pois he lastima estejam segos em sua ignorancia... Necessitando de entender a Arquitectura, e essa deixão à descripção do Marceneiro q faz a madeira p. ${ }^{\cdot a}$ se vazar de prata sem conhecim to do que se thes obra. Parte essecial aos Entalhadores, para fazerem o relevo de talha com propriedade, e inventarem com graça e sciencia as fabricas dos retabolos.... (...) Aos Marceneiros, p.a fazerem os Contadores, Leitos, bufetes, e mais com boa invenção; entenderem bem as plantas e riscos de outrem, e fazerem elles mesmos boas invenções e riscos... E não há Arte nem ofício, q em todo ou em parte não dependa da Arte do Debuxo. ${ }^{24}$ [grifo nosso]
}

Reconhece-se a indiscutível importância atribuída ao desenho, ideal de matriz renascimental e acadêmica; ideal da tratadística italiana já difundido pelo pensamento do século XVII em Portugal como algo fundamental
20. Moreira; Rodrigues (2011 p. 8). Ver também Toledo (1983, 2012). Sobre a circulação dos tratados artísticos no ambiente dos artesãos, ver também Brandão (2014, p. 429 e seguintes).

21. Souza (1989, p. 298).

22. Magnino (2000, p. 411 413, 418).

23. Magnino (2000, p. 411413, 418). Ver Brandão (2016, p. 14).

24. Da Costa (1967) apud Ayres de Carvalho (1977, p. 43). 
25. Conjunto de leis consuetudinárias e regras reunidas no livro manuscrito em 1572 : Livro dos Regimětos dos officiaes mecanicos da mui nobre e sëpre leal cidade de Lixboa, cujo original se encontra no Arquivo da Câmara Municipal de Lisboa. Foi transcrito por Carlos José de Araújo Vilela e impresso pela primeira vez em Coimbra, pela Imprensa da Universidade, em 1926. Livro dos Regimentos... (1926)

26. Livro dos Regimentos... (1926, p. 111).

27. Manuscrito localizado no Arquivo Municipal de Lisboa, Regimento do Officio de Carpinteiro de Moveis e Semblage. (Ref. $\mathrm{BL}$ 2A 32.03.38) apud Toledo (1983, p. 165-175). para a atividade dos artistas, pintores e escultores, mas também para os artesãos (como os marceneiros). Os exames de ofício referiam-se aos desenhos desde pelo menos 1572, porém exigiam a execução de peças tridimensionais para a avaliação dos oficiais.

Os trabalhos artesanais em Portugal, assim como em diversas regiões da Europa, obedeciam, ainda no século XVIII, às determinações herdadas das corporações de ofícios medievais, segundo as quais cada oficial mecânico deveria dedicar-se exclusivamente ao ofício para o qual se examinara. Para que um aprendiz dedicado aos trabalhos de madeira pudesse atingir o reconhecimento pelos pares e também perante a sociedade e poderes locais, deveria demonstrar sua capacidade de exercer livremente a profissão, submetendo-se ao exame de seu ofício. Muitos dos critérios para diversos exames de ofício, embora de origem medieval, ao serem compilados na segunda metade do século XVI demonstravam certa absorção do Renascimento e estabeleciam que o artesão executasse uma peça baseada num desenho, como mencionado no texto do Livro dos Regimentos dos oficiais mecânicos... ${ }^{25}$ da cidade de Lisboa.

Segundo o Livro dos Regimentos..., os ensambladores fariam um painel de sete palmos de altura e cinco palmos de largura, com sua moldura, utilizando cola feita de peixe e, depois, esse painel seria decorado com colunas dóricas, torneadas, bem proporcionadas e, sobre as colunas, faria um friso, com seus tríglifos, sua arquitrave e frontispício com proporções adequadas. Para o exame de entalhador, o artesão teria que realizar um friso com ornamentos romanos muito bem ordenados e, no centro, teria que esculpir:

um serafim muito bem-feito e de formoso rosto e em tudo segundo a ordem e o desenho que aqui vai [...] Fará um capitel coríntio de um palmo de diâmetro e a altura será proporcionada a esta divisão, o capitel será ornado de folhas e caulículos muito bem-feitos [...] na ordem das folhas e disposição de todo o ornamento deste capitel guardará as obrigações coríntias que em tudo seja conforme este desenho. ${ }^{26}$ [grifo nosso]

Há de se destacar, mais uma vez, a importância atribuída aos desenhos como modelos para que um artesão realizasse a peça exigida. No entanto, habilidade e competência seriam comprovadas de fato apenas pela realização tridimensional do objeto em proporções reduzidas. Considerando a execução exigida pelos exames mencionados acima, um painel de sete palmos de altura e cinco de largura e um capitel com um palmo de diâmetro são, com efeito, peças em escala relativamente modesta, se considerarmos as dimensões arquitetônicas.

Outro estatuto a organizar, posteriormente, o sistema de atuação dos artífices, publicado em Lisboa em 1767, foi o Regimento do Officio de Carpinteiro de Moveis e Semblage. Aqui são mencionados os exames para exercer o ofício, entre os quais deveria solicitar-se executar "um retábulo de sete palmos ou como The determinar os juízes o qual levará suas colunas e será feito dentro do preceito da Arquitetura, ordenando os juízes de qualquer das cinco ordens, e desta ha de fazer a obra de exame" ${ }^{27} \mathrm{~A}$ referência às dimensões da peça a ser executada, 
"sete palmos de altura", o que equivale aproximadamente a um metro e meio, demonstra que não se tratava de um retábulo em miniatura, porém de um exemplar em pequenas dimensões. De todo modo, ficava evidente a exigência de um esforço tridimensional para a demonstração do "saber-fazer".

Bastaria evocar, neste momento, dois exemplos de móveis em miniatura: uma cômoda papeleira da coleção do Museu de Arte Antiga de Lisboa, ${ }^{28}$ e outra papeleira da coleção do Museu de Artes Decorativas Portuguesas, Fundação Ricardo do Espírito Santo Silva ${ }^{29}$ (figuras 1 e 2). $\bigcirc$ primeiro exemplo, do final do século XVIII, é a exata reprodução de um móvel em tamanho real, com discretos elementos de talha, incrustações em diferentes colorações de madeira, puxadores e espelhos de fechaduras em metal lavrado, com apenas 44 centímetros de altura, 51 centímetros de comprimento e 29 centímetros de largura. $\bigcirc$ exemplar do Museu de Artes Decorativas Portuguesas, também uma pequena papeleira executada em pau-santo com motivos geométricos, datada do último quartel do século XVIII, com os mesmos 44 centímetros de altura, foi reconhecido pelos estudos desenvolvidos na Fundação como "prova de exame". Esclarece-nos o texto do Guia:

Depois de anos de aprendizagem, o artífice que pretendia ser considerado mestre examinado, apresentava uma obra perante um júri presidido pelos Juízes do Ofício. $\mathbf{O}$ modelo era proposto pelo júri ou pelo candidato e, geralmente, em tamanho reduzido (variável) desde que obedecesse a grande rigor de proporções e qualidade técnica - verdadeira prova de virtuosismo. Esta peça parece responder a esses requisitos..$^{30}$ [grifo nosso]

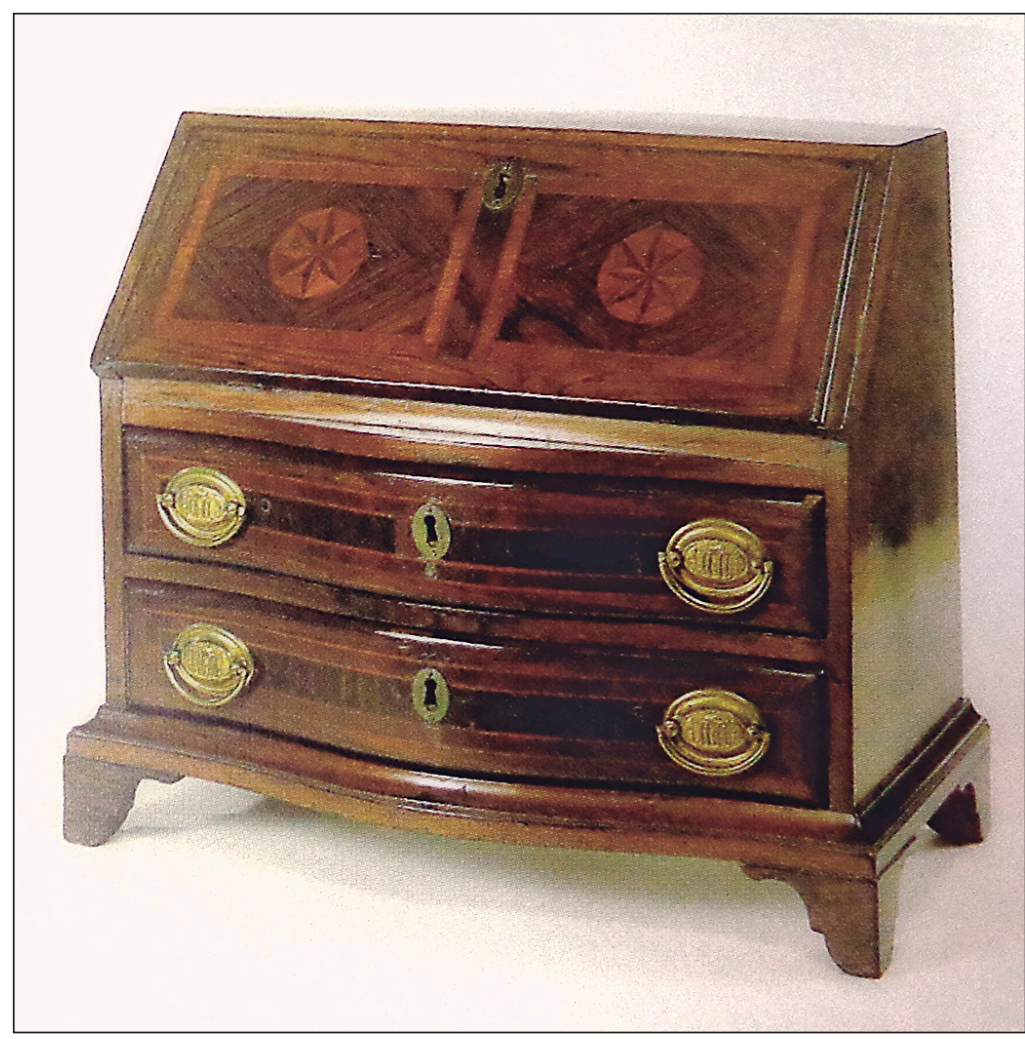

Figura 1 - Cômoda papeleira em miniatura. Portugal, final do século XVIII. Pau-brasil, jacarandá. A. $44 \mathrm{~cm}$ $\times$ C. $51,5 \mathrm{~cm} \times$ L. $29 \mathrm{~cm}$. Lisboa. Museu Nacional de Arte Antiga. Fonte: Portuguese Furniture: collection guide. Lisboa: 2000, p. 86.
28. Portuguese (2000, p. 86 , 120).

29. Guia (2001, p. 268). 30. Guia (2001, p. 268). 
31. Ponte (1990, p. 46).

32. Bastos; Souza (2004, p. 22).

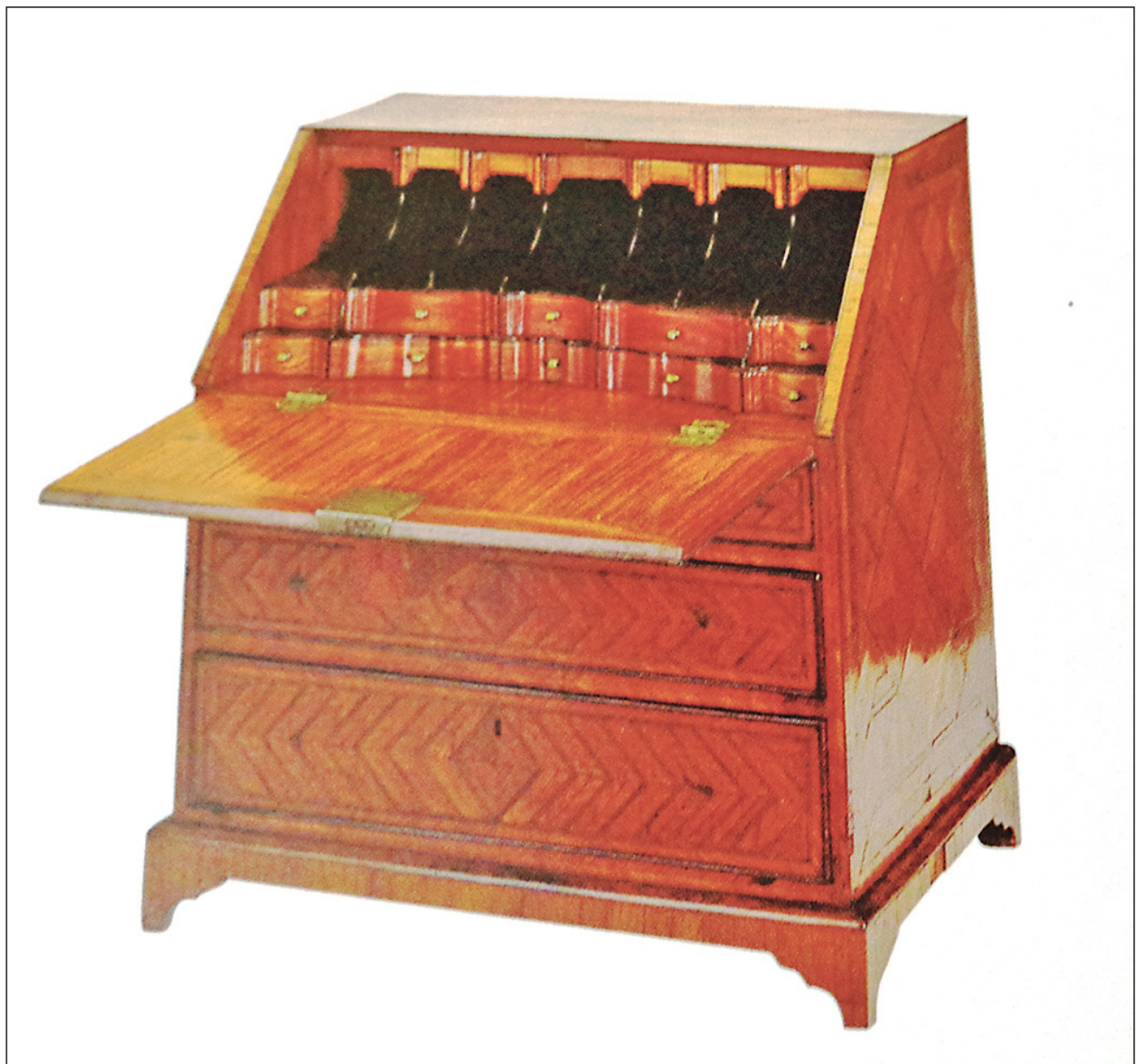

Figura 2 - Cômoda papeleira. Portugal século XVIII. Pau-rosa, pau-santo faixeado, desenhado com motivos geométricos. A. 44,8 cm $\times$ C. 43,2 cm × L. $27 \mathrm{~cm}$. Fonte: Guia. Museu-Escola de Artes Decorativas Portuguesas. Lisboa: Fundação Ricardo do Espírito Santo Silva, 2001 , p. 268.

No contexto francês, a produção de protótipos por parte de um artesão que se dedicasse à montagem ou à decoração de um móvel relacionava-se ainda com outro aspecto: a demonstração do trabalho feito em material menos nobre, porém no mesmo modelo do que seria realizado para o cliente na matéria definitiva. Muitas vezes, segundo Alessandra Ponte, um carpinteiro de móveis, um entalhador ou escultor, ao se dedicar à realização de um móvel particularmente especial, fornecia um modelo em cera, argila ou em madeira macia, que era apresentado ao cliente para ser julgado antes da realização do móvel definitivo. ${ }^{31}$ Como vimos, as regras para inventário do Instituto Português de Museus reconhecem, com relação ao mobiliário, a especificidade dos modelos e protótipos, algumas vezes feitos em dimensões menores de que as usuais, como uma tipologia própria. ${ }^{32}$

Em alguns casos, para que o cliente aprovasse um móvel a ser concretizado em tamanho natural, o artesão the fornecia primeiramente uma 
miniatura, a fim de que se pudesse julgar melhor o efeito e a forma que teria $O$ móvel definitivo. Importantes ateliês de móveis do século XVIII, como o de Thomas Chippendale na Inglaterra, apresentavam pequenos modelos em suas lojas. ${ }^{33}$

Porém, existiu igualmente na França o aspecto de fazer uso de miniaturas como provas de exame. Segundo o catálogo do Museu dos Móveis em Miniatura, do Castelo de Vendeuvre, desde a alta Idade Média, cada artesão, para passar a ser mestre nas corporações ou como trabalho de recepção, para se tornar auxiliar, deveria realizar uma obra-prima em miniatura. $\bigcirc$ acesso à maestria se fazia perante um júri de mestres. Os pequenos móveis permaneceram como "raros exemplos de perfeição" e caracterizam-se pela precisão matemática de suas dimensões, por trazerem elementos e detalhes de difícil execução, e, enfim, por seu "virtuosismo e qualidade de execução sob uma aparente simplicidade". ${ }^{34}$

$\bigcirc$ feitio de móveis e a organização do sistema de trabalho dos carpinteiros e marceneiros sofreram um processo de transformações importantes no decorrer do século XVIII, não somente em Portugal. Em grande parte, tal processo esteve relacionado ao aumento da qualidade e da variedade da mobília, assim como ao crescente domínio técnico de uma marcenaria especializada em móveis de luxo. ${ }^{35}$ Ainda que os próprios Regimentos dos oficiais mecânicos, compilados em Lisboa no ano de 1572 no Livro dos Regimentos..., tentassem estabelecer os limites entre as profissões e impedir que um artesão realizasse o ofício de outro, pode-se perceber que essas fronteiras nunca teriam sido muito precisas e criavam novos entrelaçamentos no século XVIII.

Todo o sistema de organização do trabalho dos ofícios mecânicos, herdado de modelos medievais portugueses, modificou-se certamente ao adequarse à realidade da colônia brasileira. Parece certo que, tanto em Portugal como no Brasil, a rígida divisão das funções exercidas por distintos oficiais nunca se tenha aplicado e mantido rigorosamente. Embora ainda houvesse transposição de peças de mobiliário da metrópole à colônia, o Brasil do século XVIII já contava, certamente, com uma importante produção de mobília, não apenas de aspecto tosco, destinada ao uso cotidiano, mas também aquela de caráter simbólico, associada ao luxo e à ostentação. Robert Smith salientara em seus escritos ${ }^{36}$ a importância e a qualidade artística do mobiliário produzido no período colonial brasileiro. ${ }^{37} \mathrm{Nem}$ mesmo, porém, os limites entre pintura e escultura, de um lado, e artes mecânicas, de outro, eram rigidamente estabelecidos no universo português. ${ }^{38}$ Podemos reconhecer que havia, de fato, um contexto de "sobreposições de funções". ${ }^{39}$

$\bigcirc$ Livro dos Regimentos..., contudo, determinava: "Que nenhum oficial use mais que daquilo que foi examinado". 40 No entanto, não era possível estabelecer claramente os limites entre ofícios semelhantes de modo definitivo:

E por escusar diferenças que há entre os diferentes oficiais por tomar das obras de que não são examinados ordenam e mandam que todo ensamblador que for examinado segundo este Regimento pode tomar obra de seu ofício em que entre a talha mas não para a poder fazer em sua casa e se passar por entalhador examinado e pela mesma maneira o entalhador que for examinado da maneira sobredita poderá tomar obra de
33. Le musée (s.d., s.p.).

34. Le musée (s.d., s.p.).

35. Ponte (1990, p. 46).

36. Smith (1979).

37. O historiador de arte norte-americano, estudioso do Setecentos luso-brasileiro, Robert Smith, desenvolvia nos anos 1970 trabalhos como "José Gomes de Figueiredo e o seu mobiliário pernambucano do século XVIII", publicado no The Connoisseur em 1972. Nesse estudo concluía que no Brasil "a fabricação de mobiliário atingiu um grande desenvolvimento mais elevado do que em qualquer outra parte da América Latina, durante a segunda metade do século XVIII". Indicava, então, aos pesquisadores brasileiros, importantes caminhos de estudo de atribuição de autoria a partir de observações formalistas e de levantamento de documentação. Ver Brandão (2009-2010, p. $47-48,58)$.

38. Araújo (2005, p. 41-44). 39. Santos (1942, p. 295317).

40. Livro dos Regimentos (1926, p. 234-235). 
41. Livro dos Regimentos (1926, p. 113).

42. Bluteau (1728).

43. Ver Brandão (2013a).

44. Bluteau (1728, p. 158)

45. Bluteau (1728, p. 464)

46. Bluteau (1728, p. 324)

47. Bluteau (1728, p. 25).

48. Bluteau (1728, p. 138)

49. Ponte (1990, p. 46). ensamblagem que tenha ou leve talha e não fará ensamblagem em sua casa como se fosse ensamblador examinado $[\ldots]^{41}$

Para se ter uma ideia das definições e dos limites lexicais entre os ofícios da madeira no século XVIII, recorremos ao Dicionário de Raphael Bluteau, Vocabulario portuguez \& latino: aulico, anatomico, architectonico, ${ }^{42}$ organizado entre 1712 e 1728. Esboçava-se, nesse primeiro dicionário da língua portuguesa, a compreensão dos distintos ofícios da madeira. ${ }^{43}$ Carpentaria era, na definição do dicionário de Bluteau, obra de carpinteiro, arte e ofício de carpinteiro. Carpenteiro ou carpinteiro era "o oficial que faz obras lisas de madeira" ${ }^{44}$ Como "obra lisa", podemos compreender que se referia à ausência de talha ou torneados.

Samblador ou ensamblador definia-se como "oficial que obra e junta madeira lisa e corta a meia esquadria". E ainda: "Todas essas palavras se derivam do francês Assembler que vale o mesmo que juntar e ajuntar. Não temos palavras próprias latinas. Poderás chamar a obra de Samblagem". Segue-se a expressão em latim: "opus intestinum ex variis lignis concinnatum" (obra de interiores a partir da composição de várias madeiras). ${ }^{45}$

O verbete Marcenaria ou Marceneria ou Macenaria definia-se no dicionário de 1728 como "Obra de marceneiro", seguida da expressão latina "Ligneum opus elegans, ou politius" (trabalho em madeira elegante ou polido). E Marceneiro, em Bluteau, definia-se como

Oficial que lavra a madeira com mais primor que o Carpinteiro Operis lignei elegatioris faber ou Faber operis intestinis. Por operis intestinis tomam os Doutos por obras de madeira trabalhadas com artifício \& primor com que se ornam as casas, como bofetes e contadores, como também portas e janelas, feitas com mais arte do que costumam fazer os carpinteiros ${ }^{46}$ [grifo nosso]

Talha, obra de talha, na definição do Vocabulario de Bluteau, era "toda obra que se faz de meio relevo, chama-se talha porque é entalhada pelo artífice". ${ }^{47}$ Já a palavra entalhador, define-se aqui como "oficial de obra de talha com flores de madeira, com cabeças de Anjos, com netas, brutescos [grotescas?] \& outras figuras de meio relevo obras lisas de semblagem". 48

Na França, comparativamente, os regulamentos das corporações eram, da mesma forma, muito severos e controlavam, desde a ldade Média até o correr do século XVIII, os trabalhos dos artesãos, como os chamados menuisiers e ebanistas, responsáveis pela montagem e execução de móveis de luxo, de modo a culpabilizá-los, por exemplo, caso escolhessem madeiras defeituosas, entre tantas outras exigências. $O$ menuisier, equivalente talvez ao ensamblador ou carpinteiro de móveis no contexto português, não poderia talhar e esculpir a decoração aplicada à mobília. Ao montar um móvel de madeira, deveria entregá-lo montado ao entalhador ou escultor para que somente estes realizassem a decoração. Cada profissional deveria fixar sobre o móvel sua própria marca com estampilles - marcas impressas de sua oficina. ${ }^{49}$ 
Assim como no contexto francês, os termos relacionados aos ofícios da madeira - carpinteiro, marceneiro, ensamblador, entalhador - dividiam-se em Portugal e ganhavam suas definições no dicionário de Bluteau, enquanto estabeleciam limites e peculiaridades de seus fazeres. Parecia haver, em Bluteau, o reflexo de uma particular atenção em torno da definição de marceneiro. Não por acaso, talvez, entre carpinteiros e marceneiros tenha havido conflitos registrados nos processos em Portugal na segunda metade do século XVIII. ${ }^{50}$

Essa problemática pode ser, em parte, esclarecida pelas modificações nas profissões ocorridas após o terremoto de Lisboa, de 1755. Segundo Langhans, a permanência dos Regimentos de Ofícios até meados do século XVIII poderia se justificar pelo caráter consuetudinário e permanente de tais relações de trabalho, cuja ruptura e desestabilização somente se observaria com o desastre de 1755. Para o autor, o terremoto causou perturbações à ordem estabelecida: "ruíram as tendas de arruamentos inteiros do mesmo ofício", muitos documentos e registros de corporações se perderam. A reconstrução de Lisboa, por outro lado, exigiu a atuação de muitos ofícios e muitos oficiais a mais que a cidade não tinha condições de oferecer, portanto, vieram artífices de outras províncias e de outros países. A Casa dos $24^{51}$ tentava, ainda e inutilmente, manter os antigos privilégios e regras da profissão. Os ofícios e suas regras começaram, então, a ceder lugar a outras formas de comércio e manufaturas. Daí nasceram os Decretos de 1761, "mas não era o fim do sistema". 52 É preciso, portanto, reconhecer ao mesmo tempo a permanência e as transformações do modelo de trabalho artesanal durante a segunda metade do século XVIII no contexto luso-brasileiro.

Desde meados do Setecentos, no contexto das modificações e ampliações no feitio de mobília em toda a Europa, iniciava-se, em Portugal, um longo transcorrer de conflitos entre marceneiros, carpinteiros e entalhadores em torno do domínio sobre a "fabricação" de mobília, contendas que envolviam o uso da palhinha austríaca e a valorização da marcenaria, o que Bluteau expressou como "mais elegante", "com mais arte", "com mais primor". Pode-se deduzir que, entre o Livro dos Regimentos... de 1572 e a necessidade de sua reformulação em 1767, importantes modificações tinham ocorrido também no que se refere aos trabalhos de marcenaria. $\bigcirc$ século XVIII assistira ao fenômeno da diversificação e especialização dos móveis e outros objetos domésticos de madeira.

Para Jaime Manoel Souza, tratou-se de um período em que houve o "entendimento mais amadurecido da arte do mobiliário":

Consciente do vasto campo de potencialidades próprias que o mobiliário the oferece, o artista conjuga formas e utilizações por vezes de maneira quase insólita. Daqui resulta um gênero verdadeiramente criativo, pautado pela diversidade e originalidade dos seus modelos. ${ }^{53}$

O novo Regimento, de 1767, "Regimento do Offício de Carpinteiros de Móveis e Sembrage" [sic], poria fim ao embate entre marceneiros e carpinteiros, ${ }^{54}$ uma vez que agrupava tais ofícios numa única profissão:
50. Brandão (2013a). Para aprofundar a compreensão dos conflitos ocorridos entre marceneiros e carpinteiros em Lisboa do século XVIII, ver Brandão (2015).

51. A Casa dos 24 era a Câmara profissional representativa das corporações nos conselhos e desempenhava um papel importante na defesa dos interesses dos artesãos.

52. Langhans (1943, p. XXV).

53. Souza (1989, p. 299).

54. Tais conflitos entre marceneiros e carpinteiros são claramente perceptíveis se observarmos a documentação primária no acervo do Arquivo da Câmara de Lisboa. Ver, por exemplo, Regimento dos Carpinteiros de Móveis e Semblage (Ref. BL 2A 32.03.38); Regimento que o Senado da Camara Da ao Oficio de Entalhador desta Cidade, Anno 1768 (Ref. BL2A 32.03.38), Livro 3. De Registro dos Regimentos dos Oficias Mecaniscos da Casa dos 24, 1768-1796, CÓD. BL2 A 32.03.40. 
55. Regimento que o... (1768). Langhans (1943, p. 495).

56. Ponte (1990, p. 48).

57. Flexor (2008).

58. Martins (1974, p. 368). Ver Brandão (2013b).
Ponderandosse na Caza dos Vinte e quatro desta Corte, a grande desordem, em que nella vivião, os dois officios de Carpinteiro chamado da rua das Arcas, que com o officio do Marsineiro, tinham conexão entre si, e que cada um dos Officios, pertendiam apropriar-se a diversas obraz, e melhorar-se; de Sorte, que o outro ficasse com grande diminuiçam os Deputados da dita Caza, se fizesse huma reprezentaçam ao Senado da Camara, para que ordenasse se unissem estes dois officios, para que assim ficasse Conservado huma paz firme, e cessarem entre elles, todas as ocazioes de pleitos, e disputas, que aperturbe, ficando ambos denominandosse daqui em diante por Carpinteiros de moveis, e Sambragem..$^{55}$

No caso francês, houve também uma reformulação dos estatutos das guildas e das corporações em 1751 antes do esfacelamento completo do sistema. Em 1791, com efeito, as corporações são definitivamente suprimidas. ${ }^{56}$ Tinha início, na Inglaterra, a Revolução Industrial, e o universo do trabalho artesanal e manufatureiro ingressaria num doloroso e gradativo processo de fragmentação de valores mantidos desde a ldade Média. ${ }^{57}$

Contudo, não apenas o agrupamento das profissões de carpinteiro e marceneiros em Lisboa de 1767, mas diferentes caminhos nos levam a concluir que os trabalhos artísticos e artesanais sobre madeira, em suas variadas modalidades, entrelaçavam suas atividades nas mãos de distintos oficiais. A versatilidade de certos artesãos transparecia, portanto, na sequência de seus trabalhos de natureza bastante diversa. Os Regimentos nos proporcionam compreender, ao menos hipoteticamente, a transmissão de um sistema de trabalho artesanal de Portugal para o Brasil. Esse modelo ideal a ser seguido perdurou, como vimos, até o século XVIII.

Além disso, os Regimentos nos ensinam as ambiguidades do fenômeno que nós chamamos, hoje, de "arte" e de "artista", quando nos referimos ao período colonial no Brasil. Nesse contexto, a produção de mobiliário, das artes aplicadas de um modo geral e a produção de talha e escultura estariam muito mais aproximadas do que podemos imaginar. Exemplo muito claro dessa dinâmica de sobreposição de funções e de um embaralhamento na ideia de hierarquia das artes é o fato de que, reconhecidamente, o mais importante escultor brasileiro do período colonial, Antônio Francisco Lisboa, o Aleijadinho (Vila Rica/Ouro Preto 1730 c.1814), poucos anos após receber o pagamento pelo monumental conjunto de esculturas de Congonhas do Campo - "pela fatura dos Profetas", conforme o Livro de Despesas do Santuário de Bom Jesus do Matosinhos, assinou outros recibos pelo feitio de "uns castiçais", além de ter sido responsável, conforme sugerido por atribuições, pela execução de mobília. ${ }^{58}$

Embora se deva reconhecer uma linha divisória entre móveis toscos "brancos", destinados ao uso cotidiano, feitos por carpinteiros, como trabalhos "em madeira lisa", de um lado, e de outro móveis em jacarandá entalhado como objetos detentores de complexas funções simbólicas, litúrgicas e honoríficas, é importante identificar determinadas manifestações que somam - num mesmo objeto - as formas e funções da estatuária sacra e a demonstração das habilidades do "escultor" também no campo da marcenaria. Partiríamos desse princípio para 
compreender a inserção de móveis em miniatura na representação de determinadas iconografias da estatuária religiosa.

Castelo de Vendeuvre, ao noroeste da França, abriga o Museu do Mobiliário em Miniatura, considerado como o primeiro e mais importante acervo do gênero no mundo, com cerca de oitocentas pequenas peças de móveis que vão desde o século XVI ao estilo art déco. Do ponto de vista museológico, a coleção foi organizada em temas que acabam por definir alguns dos sentidos das miniaturas de móveis, como temos visto: modelos e maquetes; obras-primas de mestres e auxiliares; recriações (objetos feitos em miniaturas enquanto tais, como presente, sinal de amizade ou reconhecimento); tabletterie (tabuleiros de jogos e outras peças com incrustações em madeira e marfim, destinados a guardar pequenos pertences, ao modo de cofres ou portajoias); móveis de crianças (brinquedos); e mobiliário religioso. ${ }^{59}$ Podemos apontar a diferente compreensão que fundamentou a classificação das miniaturas de móveis no Museu de Vandeuvre e aquela que foi estabelecida pelo Instituto Português de Museus, como vimos. ${ }^{60}$

Com relação ao mobiliário religioso, abrigado pela coleção de móveis em miniatura do Castelo de Vendeuvre, o museu considera que muitas vezes tais miniaturas estiveram associadas a motivos funerários. As representações do repouso de Jesus sentado sobre pequeninos tronos ou deitado em berços miniaturizados, no interior das igrejas, tinham também a função de favorecer a meditação e a prece. Os berços de Jesus reproduziriam, em miniatura, as diversas formas de berços verdadeiros usados desde a ldade Média. Além disso, uma parte dos móveis em miniaturas da coleção de Vendeuvre, associados ao contexto religioso, refere-se a ex-votos, nos quais os móveis em miniatura eram representados em cenas de agradecimento por uma graça alcançada. ${ }^{61}$

A percepção museológica de que, nas miniaturas de móveis, inseridas em determinadas cenas sacras, haveria uma clara possibilidade de compreensão da história do mobiliário poderia ser indicada, talvez, por um único exemplo. O Museu da Casa Brasileira, em São Paulo, como um espaço destinado à exposição e pesquisa sobre a casa, o móvel e o design no Brasil, em seus aspectos históricos e atuais, expõe permanentemente uma Santa Ceia do século XIX, tridimensional, na qual mesa e cadeiras são exemplares do estilo Diretório (figura 3).

Em outras palavras, a escolha museográfica de apresentar, ao olhar do visitante, uma Santa Ceia em miniatura para incluí-la numa narrativa da história do mobiliário não é, de forma alguma, descabida. Ao contrário, as miniaturas de móveis presentes em algumas cenas ou iconografias de determinados santos "contam" para nossos olhos também uma história do mobiliário. O Museu da Fundação Ricardo do Espírito Santo e Silva expõe a miniatura de um trono vazio destinado a abrigar originalmente a figura de algum santo entronizado, cuja imagem desapareceu, como uma peça de mobiliário em miniatura com valor por si mesma (figura 4). 
Figura 3 - Oratório com miniatura de Santa Ceia. Cadeiras em estilo Diretório. Madeira e vidro. $68 \mathrm{~cm} \times 72 \mathrm{~cm} \times$ $56 \mathrm{~cm}$. Século XIX. São Paulo, Museu da Casa Brasileira. Fonte: www.mcb.org.br

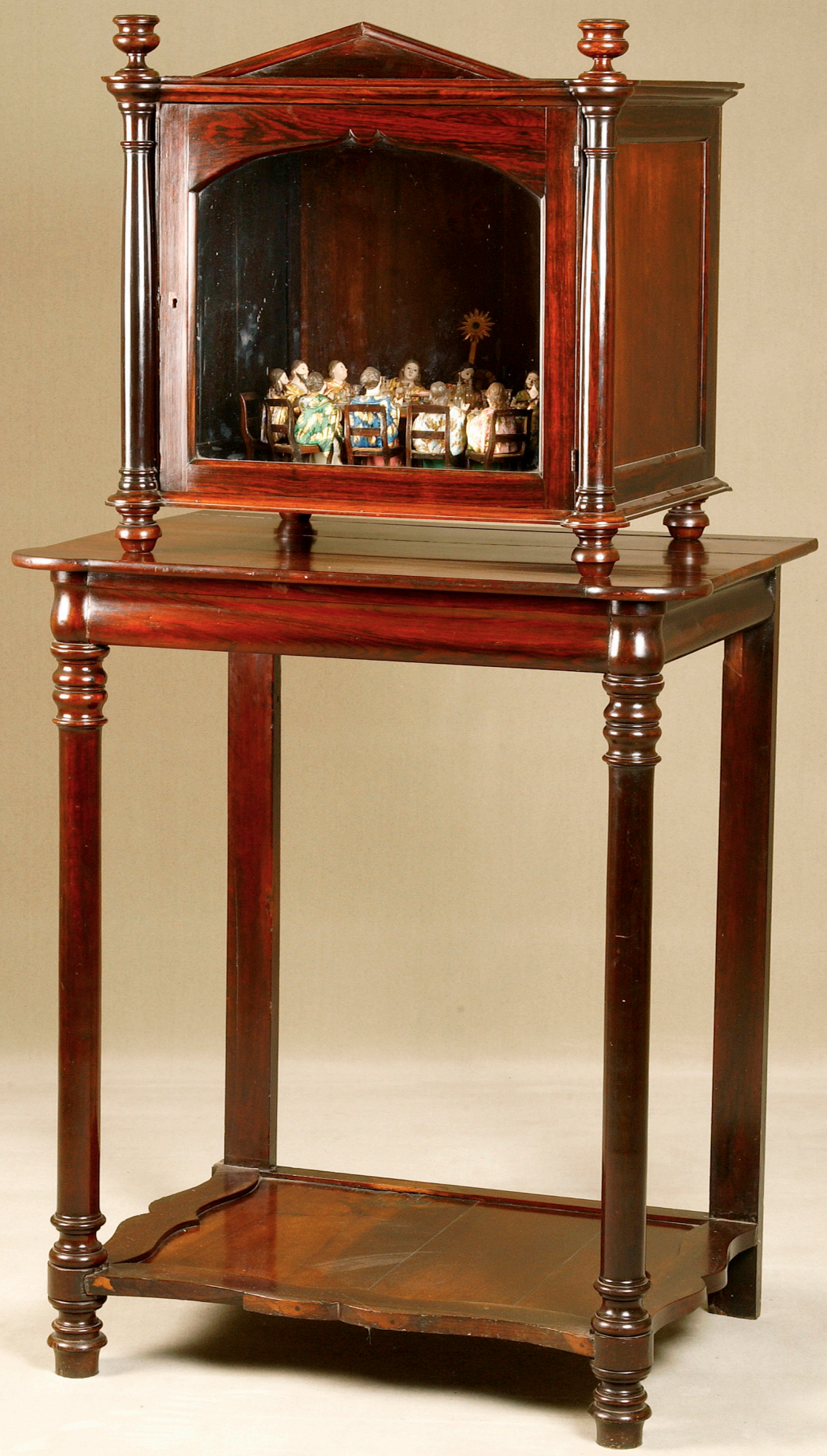


Móveis em pequeno formato fazem parte da tradição iconográfica de diversos santos: Santa Cecília é representada tocando lira ou órgão, sentada em cadeira ou tamborete. Há as representações de São Pedro entronizado; Menino Jesus adormecido em seu berço; Nossa Senhora entronada em várias de suas invocações, assim como Santana Mestra.

Figura 4 - Cadeira de imagem. Portugal, século XVIII (meados). Nogueira entalhada dourada e pintada. A. 53,3; C. 25,6; L. 20,5 cm. Fonte: Guia. Museu-Escola de Artes Decorativas Portuguesas. Lisboa. Fundação Ricardo do Espírito Santo Silva, 2001, p. 161.

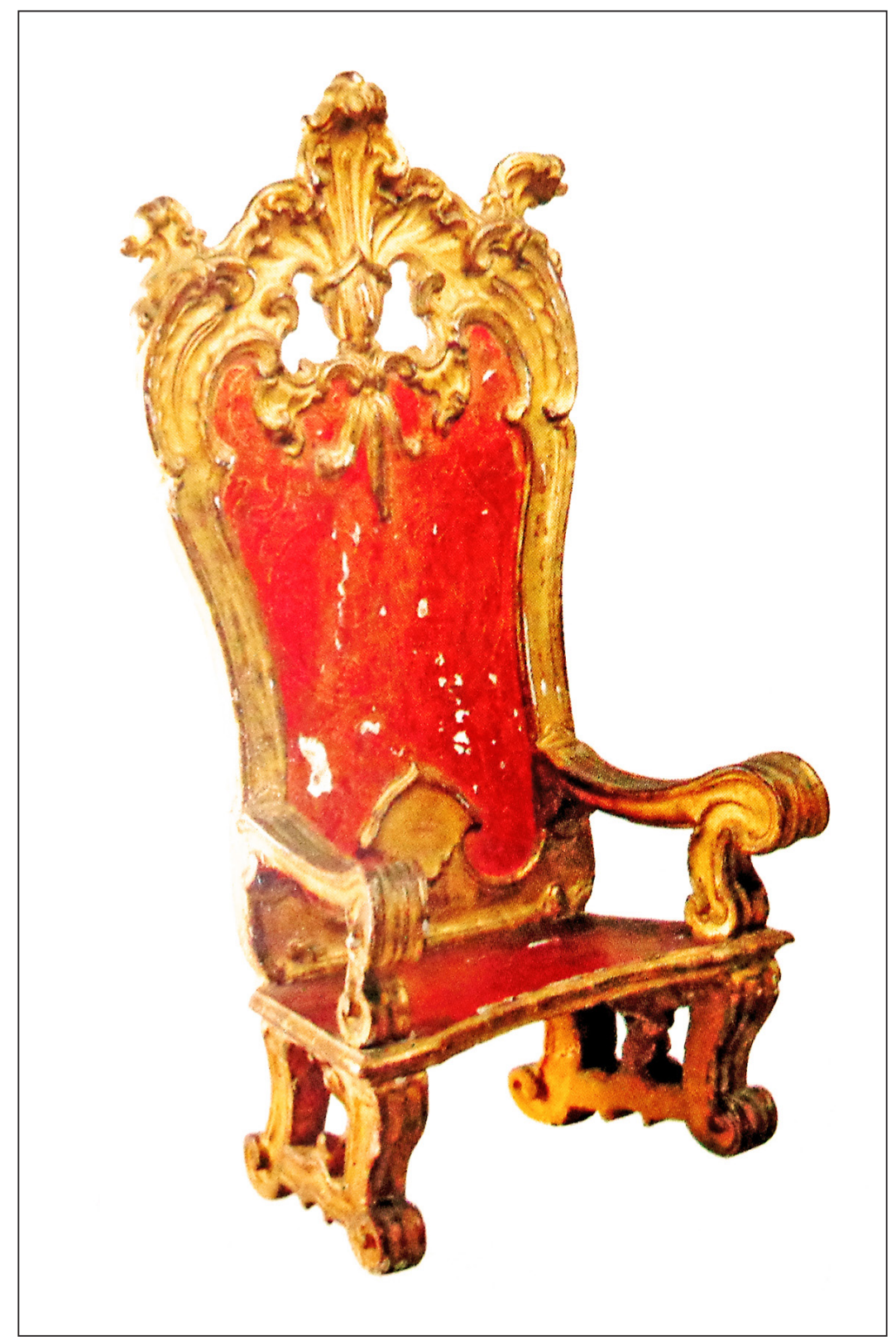


62. Esposa de São Joaquim, mãe de Maria, Santana foi inicialmente objeto de devoção no Oriente, tendo sido consagrada em Constantinopla no ano 500. No Ocidente, no entanto, Santana passou apenas a ser reverenciada depois do século VIII. O Novo Testamento não identificava, em nenhum momento, os pais da Virgem Maria, cujos nomes, Ana e Joaquim, apenas eram mencionados em textos apócrifos, como o Protoevangelho de Tiago, o Evangelho de PseudoMateus e o Evangelho da Natividade de Maria. Por volta do século XII, a devoção a Santana foi oficializada na liturgia romana, embora sua festa tenha sido instituída somente em 1481, pelo papa Sixto IV. Na arte ocidental, a partir do século XV, começam a aparecer várias representações de Santana, baseadas especialmente em episódios da Legenda Áurea. Ver: Tavares (1990, p. 18), Trindade (1994, p.1113), Museu (1997, p. 181), Alves (2005, p. 74-75) e Brandão (2010, p. 600-606).

63. Trindade (1994, p. 11).

64. Alves (2005, p. 89). A partir do inventário realizado entre 1986 e 2002, Santana Mestra aparece como a oitava invocação com maior número de representações.

65. Livro dos Regimentos (1926). É importante notar como no Regimento que vigorava desde o século XVI havia certas sobreposições entre as atividades dos carpinteiros de carpintaria "delgada", marceneiros, entalhadores e escultores. A imprecisão e a longevidade da legislação, assim como sua aplicação na colônia distante, seriam motivos suficientes para a sobreposição das tarefas entre os distintos ofícios da madeira.
Entre as representações de móveis de honra, no contexto da arte brasileira do século XVIII, encontram-se, portanto, em miniatura, os tronos associados à iconografia de Santana Mestra. ${ }^{62}$ Em conjuntos escultóricos, Santana foi comumente associada às imagens de São Joaquim ou ao lado da Virgem e do Menino Jesus. Especificamente em Portugal - e no Brasil a partir do século XVII -, a representação de Santana está quase sempre atrelada à Educação da Virgem (como Santana Guia ou Mestra), na qual a Mãe de Maria, raras vezes de pé e mais comumente sentada em rica poltrona ou cadeira de espaldar alto, estende à Menina um livro aberto. Como Santana Mestra, portanto, na cena da Educação da Virgem, Ana foi representada de pé com um livro nas mãos ao lado de Nossa Senhora Menina, sobretudo no nordeste do Brasil e sul de Portugal; ou sentada com o livro nas mãos e a Virgem Menina de pé, a seu lado, como foi mais usual no norte de Portugal e em Minas Gerais. ${ }^{63}$

No Brasil colonial, a devoção a Santana esteve relacionada à vida dos engenhos: era modelo da mãe que ensinava o catecismo, a senhora da casagrande, a esposa do patriarca. Em Minas Gerais, onde a economia se fundamentou na mineração, o culto a Santana disseminou-se largamente por ser considerada padroeira dos mineradores. A associação se dava entre a riqueza do ouro e outros minerais preciosos que se extraíam das entranhas da terra e Maria, surgida do ventre de Santana. A relação simbólica entre as minas, de onde se extraía o ouro, e o âmago de Santana, capaz de gestar a Virgem, faria de sua invocação, como Santana Mestra, uma entre as dez representações de santos mais recorrentes no contexto da arte mineira colonial. ${ }^{64}$ Isso se deveu, certamente, é preciso insistir, ao fato de ter sido adotada como padroeira dos mineradores.

Contudo, Santana Mestra foi também tomada como padroeira dos carpinteiros, e sua devoção se estendia aos marceneiros. Parece sugestiva a hipótese de que, num universo de sobreposição das atividades de ofícios semelhantes, onde muitos indícios apontam que carpinteiros dedicavam-se a encargos de marcenaria e vice-versa, ${ }^{65}$ onde havia o agrupamento de ofícios semelhantes sob uma mesma "bandeira", pudessem os artesãos, especializados em trabalhar com madeira, compartilhar uma padroeira em comum, ao lado de São José.

Cabe refletir, portanto, sobre a possibilidade de que, em se tratando da padroeira de carpinteiros e marceneiros, a representação de Santana Mestra, sentada em móvel de honra, também exigiria que se executasse, com capricho e orgulho, o móvel miniaturizado como resultado do trabalho elaborado pelos artífices da madeira. $\bigcirc$ trono em miniatura teria, aqui, uma soma de sentidos: enaltecer a idade avançada de Santana e seu papel como mestra de Maria e, ao mesmo tempo, demonstrar as habilidades próprias do ofício dos carpinteiros e marceneiros, seus devotos, capazes de reproduzir em miniatura o conhecimento do feitio de móveis em tamanho natural.

De acordo com as tradições dos grêmios da Idade Média, como vimos, e com a permanência de tais preceitos compilados no Livro dos Regimentos dos Oficiais Mecânicos até o século XVIII, os artistas-artífices eram 
divididos em corporações, segundo sua profissão. No princípio, cada corporação era simplesmente ofício de uma só profissão ou várias profissões associadas, sob a evocação de um santo padroeiro. Com o tempo, porém, esses grêmios foram acrescidos da devoção religiosa, transformando-se, então, não mais apenas em corporações de ofício laicas, mas em irmandades ou confrarias também de caráter religioso. Como as corporações identificavam-se no espaço público, em festas e procissões, pelo estandarte (bandeira) com a imagem de seu padroeiro, passaram a designar-se "bandeiras", como associações de ofícios para efeitos cívicos e religiosos, ou seja, uma organização corporativo-religiosa de um grupo de profissões.

Os diversos ofícios, agrupados em "bandeiras", eram representados por um santo patrono. $\bigcirc$ sentido religioso dos agrupamentos profissionais foi bastante significativo no contexto colonial brasileiro. Maria Helena Flexor já havia muito bem indicado o sistema de organização dos artesãos em Salvador sob um sentido tanto profissional quanto religioso. ${ }^{66}$ Jeaneth Xavier Araújo refere-se à organização do trabalho artesanal em Portugal como um modelo adotado na Colônia. Entre os indícios da permanência das tradições corporativistas no Brasil setecentista, estava justamente a integração dos oficiais mecânicos em associações de caráter cívico conhecidas pelo nome de bandeiras e em irmandades de caráter religioso. ${ }^{67}$ Cumpre dizer que entre a organização dos trabalhos dos oficiais relacionados à madeira e a devoção a São José, mas também a Santana, poderia haver uma estreita relação.

Oentendimento de que, na iconografia de Santana Mestra representada em móvel de honra miniaturizado, a escultura e o móvel foram realizados pelas mãos do mesmo artista-artífice, obriga-nos a observar alguns exemplos no conjunto dessa iconografia no Brasil colonial, com o intuito de perceber as diferentes formas de tratamento da pequena, mas solene peça de mobília.

As representações da Santa Mestra sentada mantiveram, no século XVIII, a utilização do trono como miniatura de uma cadeira, geralmente de braços, de espaldar alto e recortado, pintada de vermelho com as bordas douradas. Mas não foi esta a única forma de miniaturizar o móvel de assento, ocupado por Santana, utilizada pelos escultores no XVIII brasileiro.

Parece ter havido, basicamente, três caminhos possíveis, adotados pelos criadores de imagens de Santana no momento de conceber o pequeno assento de honra, adequados ao nível de erudição da peça, a qual tratamos aqui sem necessária ordem cronológica ou hierárquica. $\bigcirc$ primeiro caminho seria o da estilização de uma cadeira, uma solução inteligente para o escultor que dominasse pouco a linguagem do mobiliário, criando a referência indireta a um móvel para o conjunto da representação do grupo escultórico. Essa tendência à simplificação foi reforçada no século XIX, na esteira da popularização de imagens realizadas por santeiros anônimos.

segundo caminho seria a concepção de um trono com grande carga escultórica e simbólica, escapando da forma de um móvel de uso e referindo-se a
66. Flexor (1974).

67. "De acordo com as tradições dos grêmios da Idade Média, os artistas/artífices eram divididos em 12 corporações, segundo sua profissão [...]. Com o tempo, esses grêmios foram acrescidos da devoção religiosa, transformando-se então em irmandades ou confrarias. A partir de então os diversos ofícios agruparam-se em doze bandeiras, representadas cada uma delas por um santo patrono." A autora refere-se à organização do trabalho artesanal em Portugal, modelo adotado na Colônia (Araújo, 2005, p. 35). "[...] constitui ainda um indício da permanência das tradições corporativistas no Brasil setecentista a integração dos oficiais mecânicos às associações de caráter cívico conhecidas pelo nome de bandeiras e às irmandades, de caráter religioso. As primeiras [...] eram formadas pela agregação de diversos ofícios sob a custódia de um santo padroeiro [...]." Oliveira (2003, p. 178-179). 
68. Smith (1979).

69. Museu (1997, p. 175).

70. Arte (2000, p. 135).

71. Aleijadinho (2006, p. 179 e 201).

72. Disponível em: <http:// www.museuartesacra.org. br/pt/museu/obras/exibir/ santana-mestra1 $>$ e $<$ http:// www.museuartesacra.org. br/pt/museu/obras/exibir/ santana-mestra5>.

73. Arte (2000, p. 200). um móvel irreal e fortemente simbólico. $\bigcirc$ terceiro caminho seria a adoção de miniaturas de cadeiras reais de uso corrente, representadas com ou sem grandes efeitos de luxo, adequadas, em pequenas dimensões, às cadeiras de estilo nacionalportuguês, ${ }^{68}$ joanino ou Dom José l, portanto como réplicas em miniatura de cadeiras de sola ou entalhadas dos séculos XVII e XVIII. Essa terceira via reproduziria em miniatura uma cadeira "de verdade", adequada aos estilos de mobiliário dos séculos $\mathrm{XVII}$ e XVIII, datando e enaltecendo o sentido de uso e também, algumas vezes, o caráter de luxo, destacando a mobília no conjunto escultórico.

Vejamos, em seguida, uma série de exemplos da presença de tronos em miniatura nas representações de Santana Mestra no contexto da escultura brasileira colonial. Como exemplos da solução adotada em tornar o trono um objeto mais estilizado do que um verdadeiro móvel de assento, podemos mencionar uma pequena peça no Museu de Arte da Bahia, de quinze centímetros em barro cozido, policromado e dourado, do século XVIII baiano. Aqui, o trono se esconde por trás da imagem predominante de Santana e não chega nem mesmo a emoldurá-la. ${ }^{69}$ Há, igualmente, uma Santana no Museu do Ouro, em Belo Horizonte, datada da primeira metade do século XVIII, sentada sobre uma cadeira de braços fortemente estilizada. $\bigcirc$ recorte do espaldar, a ausência de talha (apenas sugerida por uma barra de pintura dourada), a disposição irreal das pernas e braços da cadeira indicam um desconhecimento ou desinteresse por parte do escultor em relação a um móvel verdadeiro. ${ }^{70}$ Da mesma forma, serviriam como exemplos de tronos estilizados os de outras Santanas do contexto setecentista mineiro, atribuídas, respectivamente, a Vieira Servas e ao Mestre de Piranga. ${ }^{71}$

Ocorrem dois exemplos importantes, referentes ao segundo caminho que sugerimos - qual seja, o da criação de um trono em miniatura de caráter fantástico. Trata-se de duas imagens de Santana Mestra do acervo do Museu de Arte Sacra de São Paulo, uma delas proveniente de Guaratinguetá e outra do Vale do Paraíba, ambas datadas do século XVIII, ${ }^{72}$ onde o trono foi transformado no depositário de representações de anjos, cabeças e patas de leões, pelas quais o caráter simbólico do móvel de assento supera seu sentido de representação de um móvel verossímil.

O terceiro caminho de representação, mais "realista" de um móvel em miniatura, por assim dizer, traz por vezes uma cadeira de linhas retas, e pode ser observado numa das Santanas Mestras do Museu Arquidiocesano de Arte Sacra de Mariana. Aqui ela aparece acomodada sobre uma perfeita réplica em miniatura de cadeira de sola em estilo nacional português. É também - caso de uma Santana classificada como de Escola Maranhense do século XVIII, proveniente do Museu de Alcântara. A Santa está disposta em cadeira sem braços, uma réplica de cadeira de uso comum, sem qualquer indicação de luxo, porém bastante verossímil. ${ }^{73}$

A representação de um móvel real, uma cadeira ou um trono, de uso mais corrente denota, muitas vezes, grande preocupação por parte dos escultores tanto em enaltecer o aspecto honorífico da mobília como de demonstrar um conhecimento atualizado de móveis de luxo do século XVIII, com dimensões proporcionais às de um móvel verdadeiro, porém com sugestões de talha 
emoldurando o encosto e ou sugerindo presença de estofamento. Poderia ser exemplo disso o móvel de Santana Mestra da segunda metade do século XVIII do Museu do Estado de Pernambuco. Aqui, a cadeira sem braços, de espaldar bastante elevado, com pernas em cabriolé de joelheiras cheias e entalhadas, emoldurada de dourado com uma pesada talha no alto do espaldar reflete, tardiamente, uma mobília joanina, ainda barroca, sem qualquer indicação ainda da leveza do mobiliário rococó. ${ }^{74}$

Já a sutileza com que um escultor baiano, da também segunda metade do século XVIII, executou a moldura do trono de sua Santana, dando a exata sugestão do predomínio das partes lisas em oposição à talha rasa, concentrada no alto do espaldar, indica o conhecimento e o domínio do vocabulário da mobília rococó, sugerindo ainda o estofamento em tecido vermelho. ${ }^{75}$

A ideia de atualidade, por parte do escultor, em adequar o objeto em miniatura associado à imagem de devoção ao estilo de móvel corrente em sua época, parece bastante sugestiva numa peça como a Santana Mestra de procedência portuguesa, pertencente ao Museu de Arte Sacra de São Luís do Maranhão, em madeira policromada e dourada. Aqui, o escultor português de final do século XVIII "atualizou" a cadeirinha de Santana adequando-a, perfeitamente, ao estilo da época, Dona Maria I, com a fina guirlanda de flores contornando o encosto ovalado e estofado. ${ }^{76}$

Antônio Francisco Lisboa, o Aleijadinho, reconhecido como o mais importante escultor brasileiro do período colonial, teria demonstrado o cuidado em executar as cadeiras em miniatura para as imagens de Santana Mestra. Tanto em imagens associadas diretamente a suas mãos como aquelas atribuídas a sua oficina, vemos que, mesmo em diferentes medidas, essas miniaturas se mantêm de modo uniforme dentro do terceiro caminho que grosseiramente sugerimos, ou seja, de representação de uma cadeira "de verdade".

Em outras palavras, nas seis imagens de Santana associadas ao nome de Antônio Francisco Lisboa, os pequenos tronos foram sempre executados com preocupações de miniaturizar um móvel de fato, com características estilísticas do mobiliário próprio ao século XVIII, ora com elementos do barroco, ora do rococó. Não obstante as razões que teriam levado o escultor a dedicar-se a essa iconografia, provavelmente motivado por encargos específicos, é provável que o fato de Santana ter sido adotada como padroeira dos carpinteiros e marceneiros sugerisse um zelo especial ao conceber o móvel sobre o qual ela se sentaria. Perdoem o anacronismo: era uma metalinguagem.

De qualquer forma, se observarmos o conjunto da obra do escultor Antônio Lisboa, veremos que a imagem de Santana Mestra foi a mais representada em sua esfera de atuação. Para Márcio Jardim: "É a padroeira dos marceneiros e carpinteiros, assim como São José, e daí se entende tê-la Antônio Francisco Lisboa representado tantas vezes e com tanto brilho". ${ }^{77}$

A primeira das Santanas atribuída a Aleijadinho encontra-se no Museu do Ouro de Sabará; datada entre 1778 e 1779, era proveniente de um altar
74. Arte (2000, p. 154)

75. Museu (1997, p. 177).

76. Arte (2000, p. 83).

77. Jardim (2006, p. 86). 
78. Oliveira; Santos Filho; Santos (2002, p. 70-71).

79. Oliveira; Santos Filho; Santos (2002, p. 94-95).

80. Oliveira; Santos Filho; Santos (2002, p. 256-257).

81. Oliveira; Santos Filho; Santos (2002, p. 262-263).

82. Oliveira; Santos Filho; Santos (2002, p. 262-263). lateral da Capela de Nossa Senhora do Pilar do Hospício da Terra Santa de Sabará. Trata-se de uma perfeita miniatura de trono e guarda semelhanças com a dinâmica do recorte do espaldar e com o entrelaçamento entre a moldura, as rocalhas e as flores, utilizadas para a decoração do cadeirão episcopal do Museu de Mariana, atribuído a Antônio Lisboa. Apresenta, ainda, um domínio por parte do escultor do repertório da talha rococó aplicada ao móvel, como a ideia de usar os vazados em oposição aos "cheios"78 (figura 5).

A segunda Santana a ser lembrada, para compreendermos a representação dos tronos em miniatura, pertence à Coleção Renato Whitaker e é datada aproximadamente do mesmo período, após $1775 .{ }^{79}$ Nesse assento adotouse a mesma ideia da Santana mencionada anteriormente, um grande encosto estofado e coroado com rocalhas e elementos vazados, embora aqui o espaldar não tenha recortes como no caso anterior.

O terceiro exemplo, considerado como obra de Antônio Lisboa e ajudantes, pertencente à coleção particular no Rio de Janeiro e datada entre 1791 e 1812, aproxima-se ligeiramente de uma estilização maior do trono; no entanto, embora as volutas dos braços e o cabriolé das pernas tenham sido tratados com cuidado, o espaldar estofado não mereceu o requinte visto anteriormente na execução da talha em miniatura, mas apenas uma decoração simplificada. ${ }^{80}$

Outra imagem de Santana Mestra associada a Antônio Francisco Lisboa e sua oficina encontra-se no Museu Arquidiocesano de Arte Sacra de Mariana, datada entre 1791 e 1812. Considerada como obra de um de seus "bons oficiais", a imagem provinha da Capela de Santana, matriz do arraial de Abre Campo. Embora o escultor tenha reduzido a altura do espaldar, aumentando o peso da talha, conserva a mesma intenção de enobrecer o móvel de assento e de atualizá-lo de acordo com a mobília da segunda metade do XVIII, sem recorrer à leveza dos vazados ${ }^{81}$ (figura 6).

Dois outros exemplos relacionados à oficina de Antônio Francisco Lisboa, que contribuem para compreender a representação do móvel em miniatura associado à estatuária sacra no contexło colonial brasileiro, são a Santana Mestra do Museu de Arte Sacra de São Paulo e a Santana da Capela de Santana do Distrito de Antônio Dias, em Ouro Preto. Em ambas, o oficial adotou um novo tipo de mobília não empregado nos exemplos anteriores, uma cadeira de braços com espaldar sem estofamento, mas recortado com tabela central também vazada. A cadeira da Santana do Museu de Arte Sacra de São Paulo é uma perfeita miniatura de um móvel corrente do estilo Dom José 182 (figura 7).

Por outro lado, a imagem da Capela de Santana tem uma estranha cadeira, com pernas muito baixas e grossas, e espaldar muito recortado. Tal "estranheza" deve-se talvez ao fato de que o escultor, embora inspirado num móvel verdadeiro, tenha ampliado em demasia para os lados a moldura do espaldar, afastando-o num vazio desproporcionado, da tabela central, talvez para acomodar melhor a imagem da Santa. Mas parece sugestivo o interesse do artista em reforçar esse novo aspecto, muito atual, dos móveis: o sentido de leveza física e visual que os encostos vazados proporcionariam às cadeiras do século XVIII. 


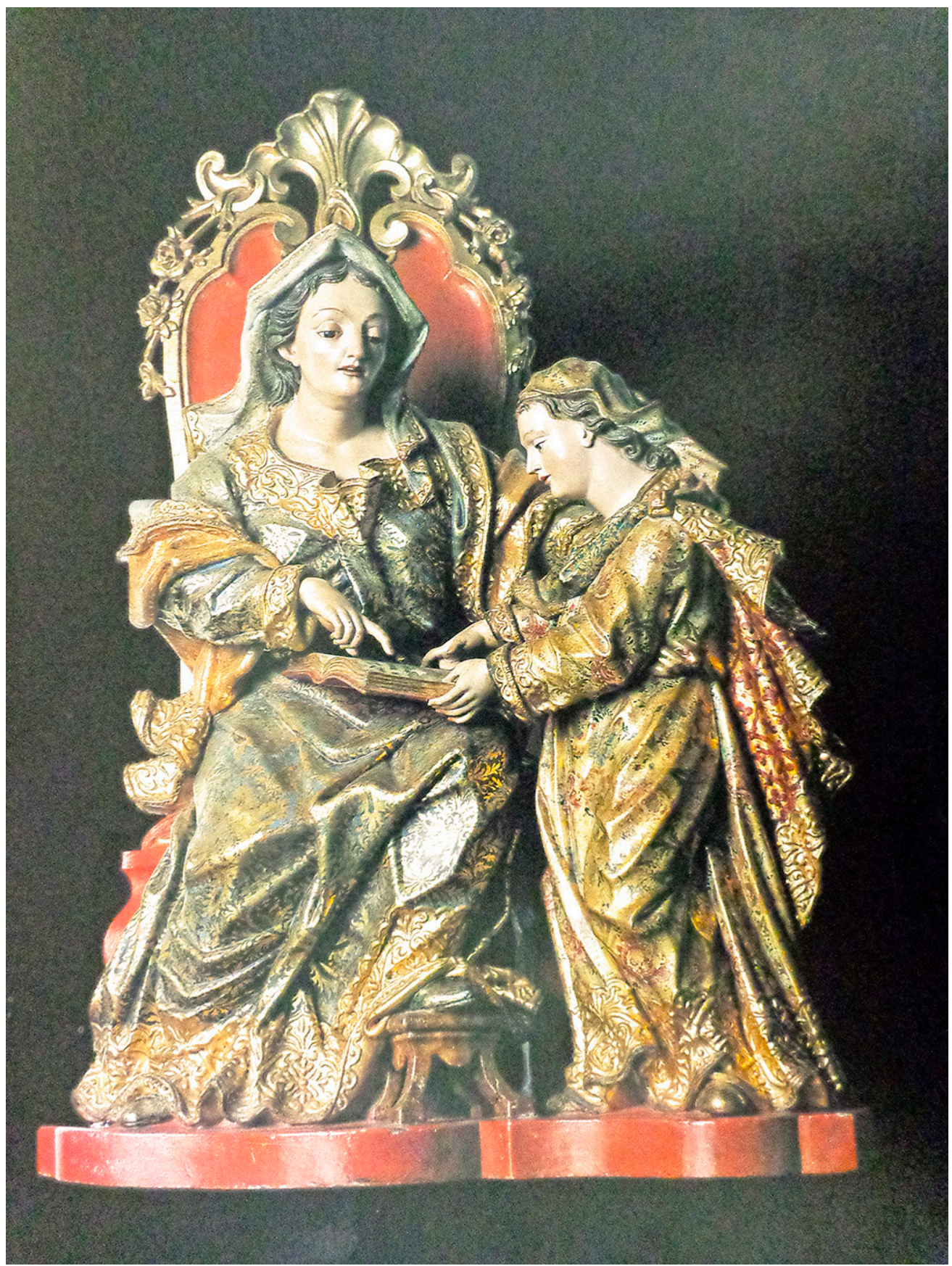

Figura 5 - 1775-79. Antônio Francisco Lisboa. (atr.) Santana Mestra. Madeira dourada e policromada. $94 \times 60 \times 44$ cm. Museu do Ouro, Sabará. Fonte: OLIVEIRA et alii. Catálogo das esculturas... Fotografia de Henry Yu. 


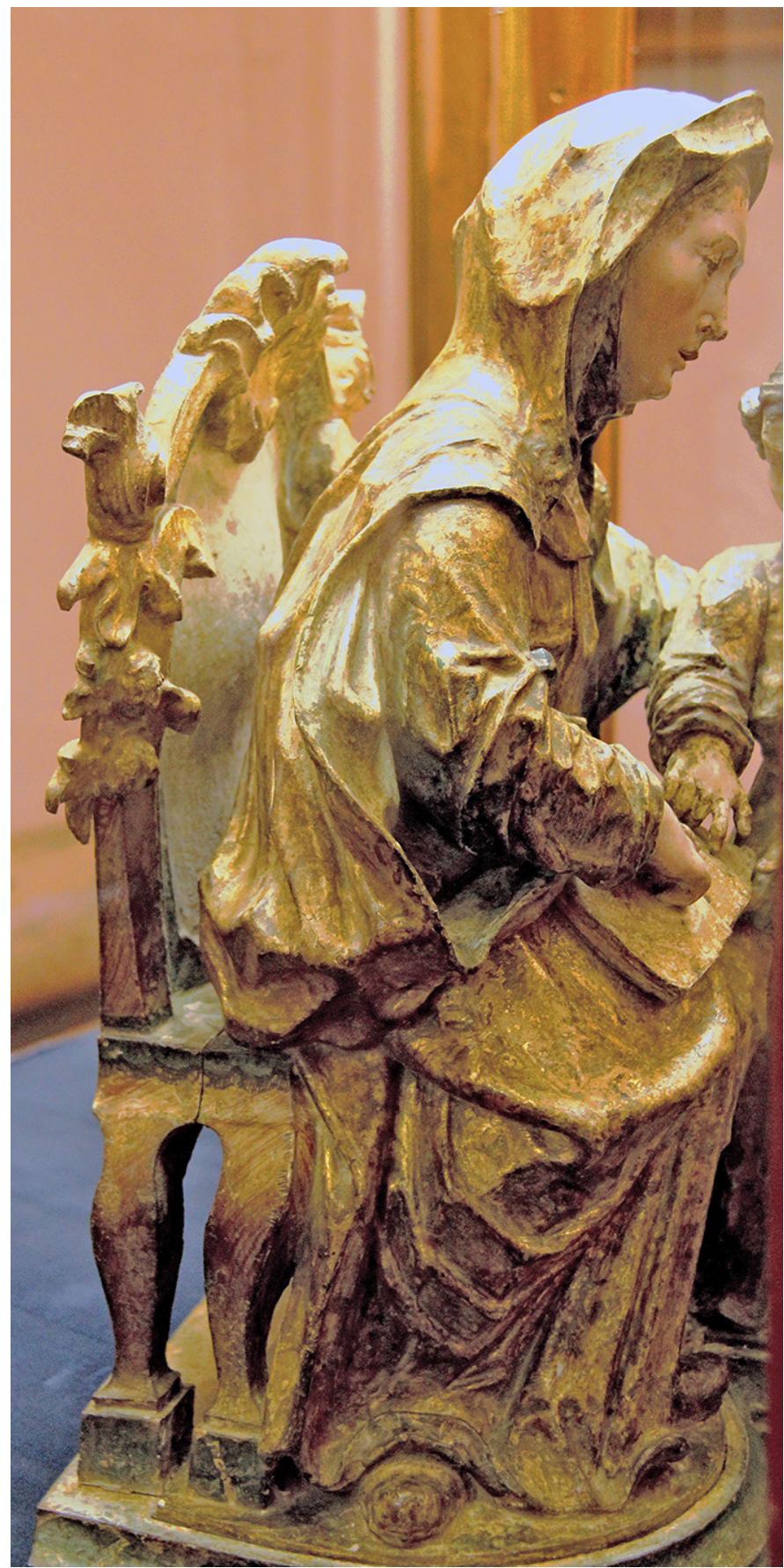

Figura 6 - 1791-1812 oficina de Aleijadinho. Madeira dourada e policromada $59 \times 46 \times 37 \mathrm{~cm}$. Museu Arquidiocesano de Arte Sacra de Mariana. Foto da autora. 


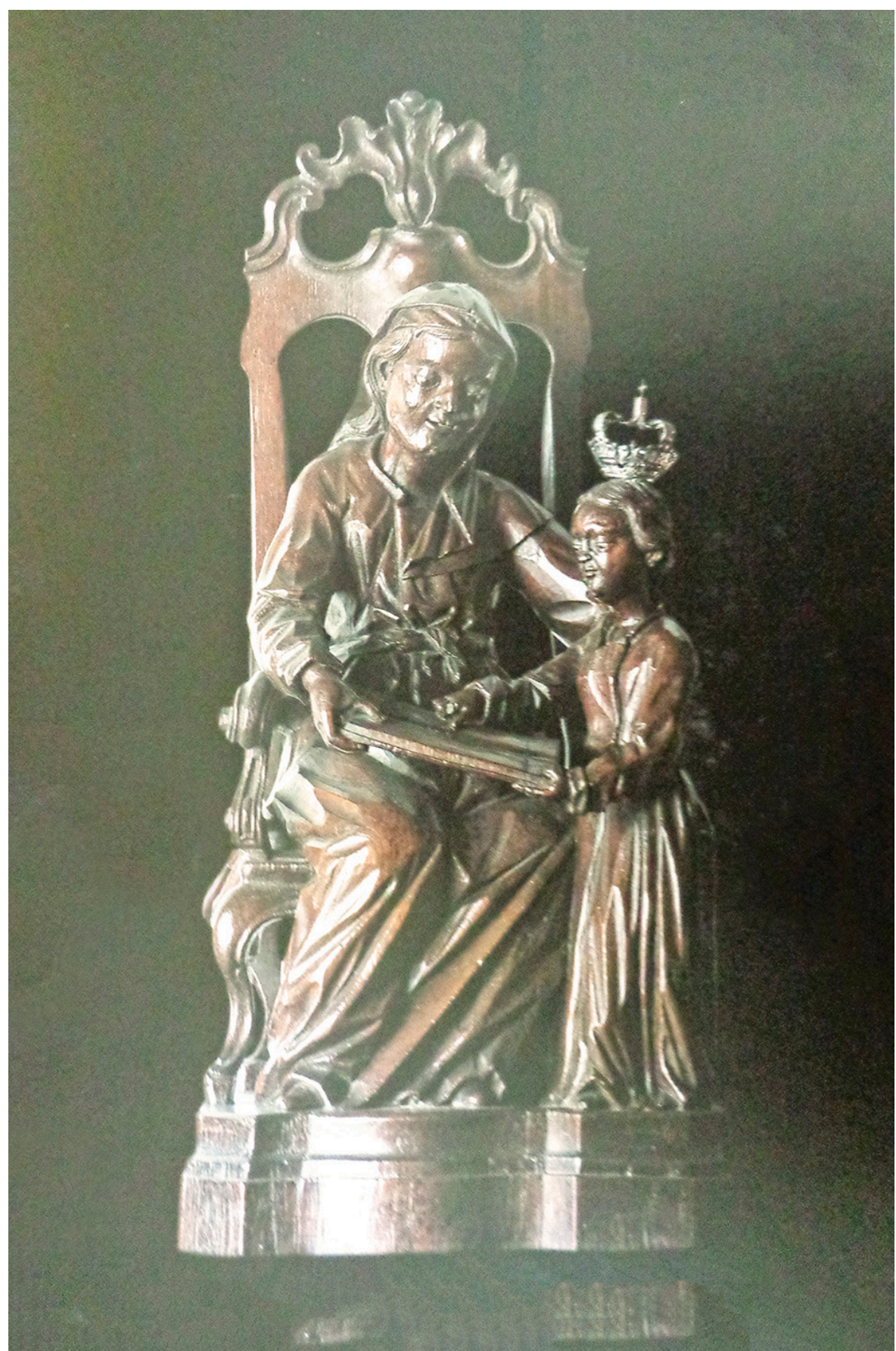

Figura 7 - 1791-1812. Oficina de Aleijadinho. Madeira encerada $57 \times$ $25 \times 24 \mathrm{~cm}$. Museu de Arte Sacra de São Paulo. Fonte: OLIVEIRA, M.A.R. et alii. Catálogo das esculturas...Fotografia de Henry Yu 
Vimos diferentes exemplos da presença de móveis em miniaturas nas representações de Santana Mestra no contexto da escultura brasileira colonial e, mais especificamente, na obra de Antônio Francisco Lisboa. Desproporções, estranhezas, verossimilhanças, sobreposições entre os estilos de mobílias verdadeiras e imaginárias, Dom José I e Dom João $V$, enfim, constituem-se como um conjunto de ajustes utilizados pelos escultores/marceneiros tanto para demonstrar a maturidade e sabedoria de Santana, no momento da educação da Virgem, quanto o visível esforço para enaltecer a profissão de seus devotos, carpinteiros e marceneiros. Esse conjunto de ajustes, por assim dizer, afinal, não parece muito distante de um processo de miniaturizar a linguagem do mobiliário e de dar um sentido de atualidade estilística, de gosto francês, associada a certo conforto para sentar-se, próprio do século XVIII.

As miniaturas de móveis demonstram, enfim, o fundamental diálogo entre as diversas formas artísticas no século XVIII. A presença de mobiliário em escala reduzida na representação de Santana Mestra como atributo iconográfico, mas também como demonstração de um "saber fazer" e, portanto, sinal da capacidade técnica e estilística por parte de um escultor-marceneiro, não parece ser um mero detalhe. Ao contrário, pode-se perceber, aqui um elemento fundamental para averiguar a combinação de significados entre o patronato, a "bandeira" como agremiação religiosa e profissional e a sobreposição das tarefas (carpinteiros, marceneiros, ensambladores, entalhadores e escultores), além de envolver-nos no mais amplo sentido lúdico e mágico das miniaturas. 


\title{
REFERÊNCIAS
}

\author{
FONTES MANUSCRITAS
}

LIVRO dos Regimentos dos Officiaes Mecanicos da Mui Nobre e Sëpre Leal Cidade de Lixboa - 1572 Arquivo da Câmara de Lisboa.

REGIMENTO dos Carpinteiros de Móveis e Semblage. Arquivo da Câmara de Lisboa (ref. Bl 2a 32.03.38).

REGIMENTO que o Senado da Camara Da ao Oficio de Entalhador desta Cidade, Anno 1768. Arquivo da Câmara de Lisboa (ref. B12a 32.03.38).

LIVRO 3. De Registro dos Regimentos dos Oficias Mecaniscos da Casa dos 24, 1768-1796. Arquivo da Câmara de Lisboa (ref. Bl2 a 32.03.40).

\section{FONTES IMPRESSAS}

BLUTEAU, Rafael. VOCABULARIO PORTUGUEZ \& LATINO, aulico, anatomico, architectonico. Coimbra: Collegio das Artes da Companhia de Jesus, 1728. Disponível em: <www.brasiliana. usp.br/dicionário>.

CORREIA, Vergílio. Prefácio. In: Livro dos Regim \tos dos officiaes mecanicos da mui nobre e sëpre leal cidade de Lixboa -1572. Publicado e prefaciado pelo Dr. Vergílio Correia. Coimbra: Imprensa da Universidade, 1926.

DA COSTA, Félix. Antiguidade da Arte da Pintura, sua nobreza, Divino e Humano que a exercitou e honras que os Monarcas fizeram a seus Artífices. [s.1.]: [s.n], 1685-1688.

. The Antiquity of Painting by Felix da Costa. Introduction and notes by George Kubler. New Haven; London: Yale University Press, 1967.

LIVROS, ARTIGOS E TESES

ALEIJADINHO e seu tempo: fé, engenho e arte. Rio de Janeiro: Centro Cultural Banco do Brasil, 2006. 
ALVES, Célio Macedo. Um Estudo Iconográfico. In: COELHO, Beatriz. Devoção e Arte. Imaginária Religiosa em Minas Gerais. São Paulo: Edusp, 2005.

ANDRIANOU, Dimitra. The Furniture and Furnishings of Ancient Greek Houses and Tombs. Cambridge University Press: Cambridge, 2009.

A World in Miniature: Greek Hellenistic Miniature Furniture in Context BABesch. Annual Papers on Mediterranean Archaeology, vol. 82, n. 1, p. 41-50, 2007.

ARAÚJO, Jeaneth Xavier de. A pintura de Manoel da Costa Ataíde no contexto da época moderna. In: CAMPOS, Adalgisa Arantes (Org.). Manoel da Costa Ataíde: aspectos históricos, estilísticos, iconográficos e técnicos. Belo Horizonte: C/Arte, 2005.

ARTE Barroca. Mostra do Redescobrimento. São Paulo: Fundação Bienal de São Paulo, 2000.

BASTOS, Celina; SOUZA, Maria da Conceição Borges. Mobiliário, Artes Plásticas, Artes Decorativas. Normas de Inventário. Lisboa: Instituto Português de Museus, 2004.

BENJAMIN, Walter. Livros Infantis Antigos e Esquecidos (1924). História Cultural do Brinquedo (1928). Brinquedo e Brincadeiras (1928). In: Magia e Técnica, Arte e Política. São Paulo: Brasiliense, 1985.

BRANDÃO, Angela. Anotações para uma história do mobiliário brasileiro do século XVIII. Revista CPC, São Paulo. n. 9. p. 42-64, nov. 2009/abr. 2010. Disponível em: <http://www. revistas.usp.br/cpc/article/view/15654>. Acesso em 11 mar 2016.

A contenda entre um carpinteiro de móveis e um escrivão de seu ofício. In: ANAIS do XXXV Colóquio do Comitê Brasileiro de História da Arte. Novos Mundos, Fronteiras, Inclusão e Utopias, 2015. Disponível em: <http://www.cbha.art.br/colóquios>. Acesso em 11 out 2016.

Sobreposição de Tarefas: uma Leitura do Dicionário de Judith Martins. In: ANAIS do XXXIIII Colóquio do Comitê Brasileiro de História da Arte, 2013a. Disponível em: <http:// www.cbha.art.br/coloquios/2013/anais/anais2013.pdf>.

Mobiliário atribuído a Antônio Francisco Lisboa. Revista de História da Arte e Arqueologia, n. 19 jan./jun. 2013b. Disponível em: <http://www.unicamp.br/chaa/rhaa/ downloads/Revista\%2019\%20-\%20artigo\%205.pdf>. Acesso em 11 out 2016.

O Livro dos Regimentos dos Oficiais Mecânicos e os Estudos Arquitetônicos da Biblioteca Nacional de Portugal: uma interpretação. VIS: Revista do Programa de PósGraduação em Arte da UnB, Brasília, 2016, v. 15, n. 2, p. 8-21. Disponível em: <http:// periodicos.unb.br/index.php/revistavis/article/view/19949/14324>. Acesso em 11 out 2016.

Santana Mestra e seu trono em miniatura. In: ANAIS do XXX Colóquio do CBHA. Rio de Janeiro, 2010, p. 600-606. Disponível em: <http://www.cbha.art.br/colóquios>. Acesso em 11 out 2016.

Tratados de Arquitetura e o Livro dos Regimentos: uma sutil referência. In: ANAIS do XXXIV Colóquio do Comitê Brasileiro de História da Arte, Uberlândia, 2014. p. 429 e ss. Disponível em: <http://www.cbha.art.br/colóquios>. Acesso em 11 out 2016. 
CARVAlHO, Ana Godinho Coelho Dotti de. A papeleira miniatura chinesa da Casa-Museu Dr. Anastásio Gonçalves e o comércio do século XVIII. Lisboa, 2010. Dissertação (Mestrado em Arte, Patrimônio e Teoria do Restauro). Departamento de História da Arte. Faculdade de Letras de Lisboa. Universidade de Lisboa.

CARVAlHO, Ayres de. Catálogo da Colecção de Desenhos. Lisboa: Biblioteca Nacional de Lisboa, 1977.

DARBYSHIRE, Lydia. The Collectors Encyclopaedia of Toys and Dolls. New York: Chartwell House, 1991.

DELOACHE, Judy; MENDOZA, Olga; ANDERSON, Kathy. Multiple Factors in Early Symbol Use: Instructions, Similarity, and Age in Understanding a Symbol-Referent Relation. Cognitive Development, 1999, v. 14, p. 299-312.

FLEXOR, Maria Helena. Mobiliário baiano. 2. ed. Brasília: IPHAN; Programa Monumenta, 2009. V. 1.

. Mobiliário brasileiro dos séculos XVIII e XIX: metodologia de pesquisa. In: TIRAPELI, Percival (Org.). Patrimônio Sacro na América Latina: arquitetura, arte, cultura. São Paulo: Arte Integrada; UNESP; Instituto de Artes; FAU/USP, 2015, v. 1, p. 189-212.

. De oficial mecânico a operário ou artista: o Liceu de Artes e Ofícios e a Academia de Belas Artes da Bahia. In: CAVALCANTI, Ana; DAZZI, Camila; VALLE, Arthur (Org.). Oitocentos: Arte brasileira do Império à Primeira República. Rio de Janeiro: EBA-UFRJ/DezenoveVinte, 2008 , v. 1, p. $145-157$.

Mobiliário Brasileiro - Babia. São Paulo: Espade, 1978.

Os oficiais mecânicos (artesãos) de Salvador e São Paulo no período colonial.

Psicanálise \& Barroco em Revista, Belo Horizonte, v. 17, p. 139-154, 1996.

Oficiais Mecânicos da Cidade de Salvador. Salvador: Prefeitura Municipal/ Departamento de Cultura, 1974.

FRAISER, Antonia. History of Toys. London: Weidenfeld \& Nicolson, 1966.

GUIA Museu-Escola de Artes Decorativas Portuguesas. Lisboa: Fundação Ricardo do Espírito Santo Silva, 2001.

JARDIM, Márcio. Aleijadinho, Catálogo Geral da Obra. Belo Horizonte: RTKF, 2006.

LANGHANS, Franz Paul. As Corporações dos Ofícios Mecânicos: Subsídios para sua história. Com um estudo do prof. Marcello Caetano. 2 vols. Lisboa: Imprensa Nacional de Lisboa, 1943.

LE MUSÉE du mobilier miniature, première collection au monde. [s.n.t.] Disponível em: <http:// www.vendeuvre.com/presse/cmusee.pdf>. Acesso em 11 out 2016.

LUCIE-SMITH, Edward. Furniture: a concise history. London: Thames \& Hudson, 2000. 
MAGNINO, Julius Schlosser. La Letteratura Ariística. Milano: Paperback Classici, 2000.

MARTINS, Judith. Dicionário de Artistas e Artífices dos Séculos XVIII e XIX em Minas Gerais. Rio de Janeiro: Instituto do Patrimônio Histórico e Artístico Nacional, 1974.

MOREIRA, Rafael; RODRIGUES, Ana Duarte (coord.). Tratados de Arte em Portugal. Lisboa: Scribe, 2011.

MOREIRA, Rafael. O mundo dos Tratados. Apresentação. In: MOREIRA, Rafael; RODRIGUES, Ana Duarte (Coord.). Tratados de Arte em Portugal. Lisboa: Scribe, 2011.

MUSEU de Arte da Bahia. São Paulo: Banco Safra, 1997.

$\mathrm{OH}$, Yeonjoo et al. The Designosaur and the Furniture Factory: Simple Software for Fast Fabrication. In: 2nd Int. Conf. on Design Computing and Cognition. Chicago: Design Society, 2006. Disponível em: <http://code.arc.cmu.edu/archive/upload/Oh.0.pdf>. Acesso em 11 out 2016.

OLIVEIRA, Myriam Andrade Ribeiro de. O Rococó religioso no Brasil e seus antecedentes europeus. São Paulo: Cosac \& Naify, 2003.

; SANTOS FILHO, Olinto Rodrigues dos; SANTOS, Antônio Fernando Batista dos. $O$ Aleijadinho e sua oficina. Catálogo das esculturas devocionais. São Paulo: Capivara, 2002.

PONTE, Alessandra. Mobiliário do Século XVIII. Lisboa: Presença, 1990.

PORTUGUESE Furniture: collection guide. Lisboa: Museu Nacional de Arte Antiga, 2000.

PROENÇA, José António. Mobiliário da Casa-Museu Dr. Anastácio Gonçalves. Lisboa: IPM, Casa-Museu Dr. Anastácio Gonçalves, 2002.

ROZENSTRATEN, Artur Simões. Aspectos da história das maquetes e modelos tridimensionais de arquitetura no Egito Antigo. In: Arquitextos, v. 12, 2011. Disponível em: <http://www. vitruvius.com.br/revistas/read/arquitextos/12.137/4037>. Acesso em 11 out 2016.

SÁ, Cristina Cunha da Costa e. A Aldeia Karajá de Santa Isabel do Morro. Revista Projeto, São Paulo, v. 23, 1980.

SANTOS, Noronha. Um litígio entre marceneiros e entalhadores no Rio de Janeiro. Revista do SPHAN, Rio de Janeiro, n. 6, p. 295-317, 1942.

SMITH, Robert. Igrejas, casas e móveis. Aspectos da arte colonial brasileira. Recife: Universidade Federal de Pernambuco, 1979.

SOUZA, Jaime M. Mobiliário. In: Dicionário da Arte Barroca em Portugal. Lisboa: Presença, 1989, p. 296-300.

STEWART, Susan. On longing: narratives of the Miniature, the Gigantic, the Souvenir, the Collection. Durham, London: Duke University Press, 2003. 
TAVARES, Jorge Campos. Dicionário de Santos. Porto: Lello \& Irmãos, 1990.

TOLEDO, Benedito Lima de. A Influência dos Tratadistas, a Obra de Serlio e Vignola e os Regimentos de Ofícios. In: Esplendor do Barroco Luso-Brasileiro. Cotia: Ateliê Editorial, 2012

Do século XVI ao início do século XIX: maneirismo, barroco e rococó (A obra de Serlio e Vignola e os Regimentos de Ofícios). In: ZANINI, Walter. História Geral da Arte no Brasil. São Paulo: Instituto Walther Moreira Salles, 1983.

TRINDADE, Silvana Cançado. A Geografia do Sagrado nas Minas Colonial. In Oratórios da Fé. Oratórios Brasileiros. Coleção Angela Gutierrez. S/1: Formato, 1994, p. 11-13.

VENDEUVRE, Elyane. Le Mobilier Miniature: les essenciels du patrimoine objets et collection. Vendeuvre: Massin, 2010.

SITES

http://www.museuartesacra.org.br

http://www.vendeuvre.com/presse/cmusee.pdf

http://www.brasiliana.usp.br

Artigo apresentado em 11/10/2016. Aprovado em 15/02/2017. 